\title{
Performance Analysis of Solar Assisted Fluidized Bed Dryer Integrated Biomass Furnace with and without Heat Pump for Drying of Paddy
}

\author{
M. Yahya \\ Fakultas Teknologi Industri, Institut Teknologi Padang, Padang, West Sumatra 25132, Indonesia \\ Correspondence should be addressed to M. Yahya; yahya@itp.ac.id
}

Received 22 July 2016; Accepted 27 September 2016

Academic Editor: Alessandro Burgio

Copyright @ 2016 M. Yahya. This is an open access article distributed under the Creative Commons Attribution License, which permits unrestricted use, distribution, and reproduction in any medium, provided the original work is properly cited.

\begin{abstract}
The performances of a solar assisted fluidized bed dryer integrated biomass furnace (SA-FBDIBF) and a solar assisted heat pump fluidized bed dryer integrated biomass furnace (SAHP-FBDIBF) for drying of paddy have been evaluated, and also drying kinetics of paddy were determined. The SA-FBDIBF and the SAHP-FBDIBF were used to dry paddy from $11 \mathrm{~kg}$ with moisture content of $32.85 \% \mathrm{db}$ to moisture content of $16.29 \% \mathrm{db}(14 \% \mathrm{wb})$ under an air mass flow rate of $0.1037 \mathrm{~kg} / \mathrm{s}$ within 29.73 minutes and 22.95 minutes, with average temperatures and relative humidities of $80.3^{\circ} \mathrm{C}$ and $80.9^{\circ} \mathrm{C}$ and $12.28 \%$ and $8.14 \%$, respectively. The average drying rate, specific energy consumption, and specific moisture extraction rate were $0.043 \mathrm{~kg} / \mathrm{minute}$ and $0.050 \mathrm{~kg} / \mathrm{minute}$, $5.454 \mathrm{kWh} / \mathrm{kg}$ and $4.763 \mathrm{kWh} / \mathrm{kg}$, and $0.204 \mathrm{~kg} / \mathrm{kWh}$ and $0.241 \mathrm{~kg} / \mathrm{kWh}$ for SA-FBDIBF and SAHP-FBDIBF, respectively. In SAFBDIBF and SAHP-FBDIBF, the dryer thermal efficiencies were average values of $12.28 \%$ and $15.44 \%$; in addition, the pickup efficiencies were $33.55 \%$ and $43.84 \%$ on average, whereas the average solar and biomass fractions were $10.9 \%$ and $10.6 \%$ and $36.6 \%$ and $30.4 \%$ for SA-FBDIBF and SAHP-FBDIBF, respectively. The drying of paddy occurred in the falling rate period. The experimental dimensionless moisture content data were fitted to three mathematical models. Page's model was found best to describe the drying behaviour of paddy.
\end{abstract}

\section{Introduction}

In Indonesia, paddy rice is the staple food of nearly $90 \%$ of population and an economic resource of more than 30 million farmers. Indonesia is the third biggest paddy producing country worldwide with its annual production of around 78 million ton [1]. Paddy after harvest generally have a high moisture content of about $20-23 \%$ wet basis in dry season and about $24-27 \%$ wet basis in wet season [2]. At the level of this moisture content, rice is easily broken and can not be securely stored because it is very susceptible to be attacked by fungus and insect. Therefore, in order to secure long-term storage and milling, the paddy needs to be dried as soon as possible to achieve moisture content of about $14 \%$ wet basis [3]. Commonly, paddy was dried using traditional sun drying and fixed bed dryer (artificial dryer). Traditional sun drying results in low quality products and long drying time. Whereas fixed bed dryer has many disadvantages such as incapability of retaining uniform moisture content, some parts of product will be over dried and some other parts will not be dried adequately which will result in a lot of broken rice during milling process, low drying rate, and long drying time [4].

Fluidized bed dryer provides an alternative to the use of traditional sun drying and fixed bed dryer for drying of paddy. The fluidized bed dryer has some advantages such as lower initial and maintenance costs, high drying rate, uniform product moisture content, and less drying time [5, 6].

Several researchers have designed and tested the fluidized bed dryer for drying of paddy. Soponronnarit et al. [7] have designed and tested a prototype fluidized bed dryer for drying of paddy with a capacity of $0.82 \mathrm{ton} / \mathrm{h}$. The result showed that the dryer reduced the moisture content of paddy from $45 \%$ dry basis to $24 \%$ dry basis at drying air temperature of 100 $120^{\circ} \mathrm{C}$, with specific airflow rate of $0.05 \mathrm{~kg} / \mathrm{s} \cdot \mathrm{kg}$ dry matter and air velocity of $3.2 \mathrm{~m} / \mathrm{s}$. The electrical and thermal energy 
consumption were found to be about 0.53 and $1.79 \mathrm{MJ} / \mathrm{kg}$ water removed, respectively. Also, good qualities in terms of head yield and whiteness were obtained.

Ibrahim et al. [8] have investigated the performance of an industrial fluidized bed dryer for drying of paddy in Malaysia with design capacity of $25 \mathrm{t} / \mathrm{h}$. The moisture content of paddy was reduced from $36.98 \%$ dry basis to $27.58 \%$ dry basis at drying air temperature of $100-120^{\circ} \mathrm{C}$ with a feed rate (capacity) of $7.75 \mathrm{t} / \mathrm{h}$. The average drying rate was found to be $538 \mathrm{~kg}$ moisture/h, whereas the electrical and thermal energy consumption were found to be about 0.79 and $7.57 \mathrm{MJ} / \mathrm{kg}$ water removed, respectively. Also, higher head rice yield and whiteness and lower milling recovery were achieved.

However, most of the fluidized bed dryer which is used for drying of paddy is of the type of hot air dryer. It has disadvantages such as high energy consumption and the drying rate depends on the drying air temperature, to increase the drying rate which is done by increasing the drying air temperature [9]. Also, most of the energy used to heat the drying air is fossil fuels such as LPG and fuel oil, while the fossil fuel sources are limited and their prices are high and steadily increasing.

Too high drying air temperature may cause cracking of the rice kernel which in turn causes breakage during milling, thereby reducing head rice yield [10-12].

Karbassi and Mehdizadeh [13] have studied the influence of drying air temperature on quality of rough rice using a fluidized bed dryer. The moisture content of paddy was reduced from $20 \%$ dry basis to $13 \%$ wet basis at drying air temperature of $140^{\circ} \mathrm{C}$. They found that the quality of rough rice in terms of head rice yield was decreased.

To overcome the problems of the hot air dryer, several researchers have designed and tested the combination of heat pump with solar energy. Dezfouli et al. [14] have evaluated the performance of a solar assisted heat pump dryer by using cabinet type of drying chamber for drying red chilli with a capacity of $15 \mathrm{~kg}$. The moisture content of red chilli was reduced from 4 dry basis to 0.08 dry basis within 32 hours at an average temperature of $46^{\circ} \mathrm{C}$, relative humidity of $27 \%$, and air mass flow rate of $0.15 \mathrm{~kg} / \mathrm{h}$.

Şevik et al. [15] have investigated the performance of a solar assisted heat pump system by using cabinet type of drying chamber for drying of mushroom. The moisture content of mushroom was reduced from initial moisture content 13.24 dry basis to final moisture content 0.07 dry basis within 230-190 min at the drying air temperature of $45^{\circ} \mathrm{C}$ and $55^{\circ} \mathrm{C}$ with an air mass flow rate of $310 \mathrm{~kg} / \mathrm{h}$, whereas the coefficient of performance of system (COP) was in the range between 2.1 and 3.1. Also, the energy utilization ratio (EUR) and specific moisture extraction rate (SMER) were varied between 0.42 and 0.66 and 0.26 and $0.92 \mathrm{~kg} / \mathrm{kWh}$, respectively.

Mohanraj [16] has evaluated the performance of a solarambient hybrid source heat pump dryer by using cabinet type of drying chamber for copra drying under hot-humid weather conditions. The moisture content of the copra was reduced from $52 \%$ wet basis to $9.2 \%$ wet basis and $9.8 \%$ wet basis within 40 hours for trays at bottom and top, respectively, at the drying air temperature in the range between $41^{\circ} \mathrm{C}$ and $48^{\circ} \mathrm{C}$ with an average temperature of $43.2^{\circ} \mathrm{C}$, whereas the COP of the dryer was in the range between 2.31 and 2.77 with an average value of 2.54. Also, the condenser heating capacity was varied between $2900 \mathrm{~W}$ and $3750 \mathrm{~W}$ with an average value of $3290 \mathrm{~W}$, whereas the SMER was found to be about $0.79 \mathrm{~kg} / \mathrm{kWh}$.

However, the solar assisted heat pump dryer has disadvantages such as the drying air temperature being low when on cloudy and rainy days and at the night time. Also, the solar assisted heat pump dryer features are not fully operated, this due to the drying air temperature is limited, and it is caused by the limited ability of solar collectors to absorb (collect) energy from the sun. Therefore, it is necessary to provide the solar assisted heat pump dryers with an auxiliary heater, such as biomass furnace by using biomass as heat energy sources.

Yahya [9] has been designed and evaluated for the performance of a solar assisted heat pump dryer integrated with biomass furnace by using cabinet type of drying chamber for drying red chillies with a capacity of $22 \mathrm{~kg}$. The researcher reported that the dryer is able to reduce the moisture content of red chillies from 4.26 dry basis to 0.08 dry basis within 11 hours at an air mass flow rate of $0.124 \mathrm{~kg} / \mathrm{s}$, with the average drying chamber temperature and drying chamber relative humidity of $70.5^{\circ} \mathrm{C}$ and $10.1 \%$, respectively. The drying rate, the specific moisture extraction rate, and thermal efficiency of the dryer were estimated on average of about $1.57 \mathrm{~kg} / \mathrm{h}$, $0.14 \mathrm{~kg} / \mathrm{kWh}$, and $9.03 \%$, respectively. Meanwhile, the average contributions of heat energy by the collector, condenser, and biomass furnace were obtained of about $14.74 \%, 47.39 \%$, and $37.87 \%$, respectively.

However, no study has been reported yet on the performance of the solar assisted heat pump fluidized bed dryer integrated biomass furnace (SAHP-FBDIBF) for drying of paddy, and the use of solar assisted fluidized bed dryer (SAFBDIBF) for drying of this food has been rarely investigated. Moreover, limited studies have compared SA-FBDIBF with SAHP-FBDIBF.

Indonesia is located in the equator line, receives abundant solar radiation with a daily average of about $4 \mathrm{kWh} / \mathrm{m}^{2}$ [17], and also produces approximately 236 million tons of biomass per year, equivalent to about 756.083 mill GJ per year [18]. These can be used as heat energy sources in drying process.

Therefore, the objective of this study is to compare the experimental performance of SAHP-FBDIBF with SAFBDIBF for drying of paddy in Indonesia, to investigate the drying characteristics of paddy in SAHP-FBDIBF and SAFBDIBF, and also to fit the experimental data to select the best mathematical models.

\section{Material and Methods}

2.1. Experimental Set-Up. A solar assisted heat pump fluidized bed dryer integrated biomass furnace was designed and installed at the Institute of Technology, Padang, West Sumatra, Indonesia. The drying system consists of finned single-pass solar collector, heat pump, biomass furnace, fluidized bed, cyclone, and blower as shown in Figure 1. The solar collector equipped with transparent cover glass material, 


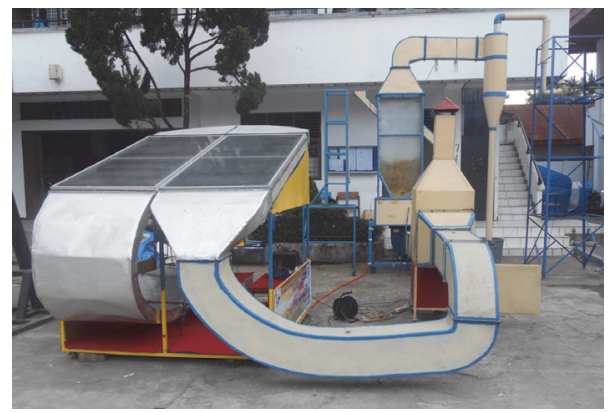

FIGURE 1: Photograph of the solar assisted heat pump fluidized bed dryer integrated biomass furnace.
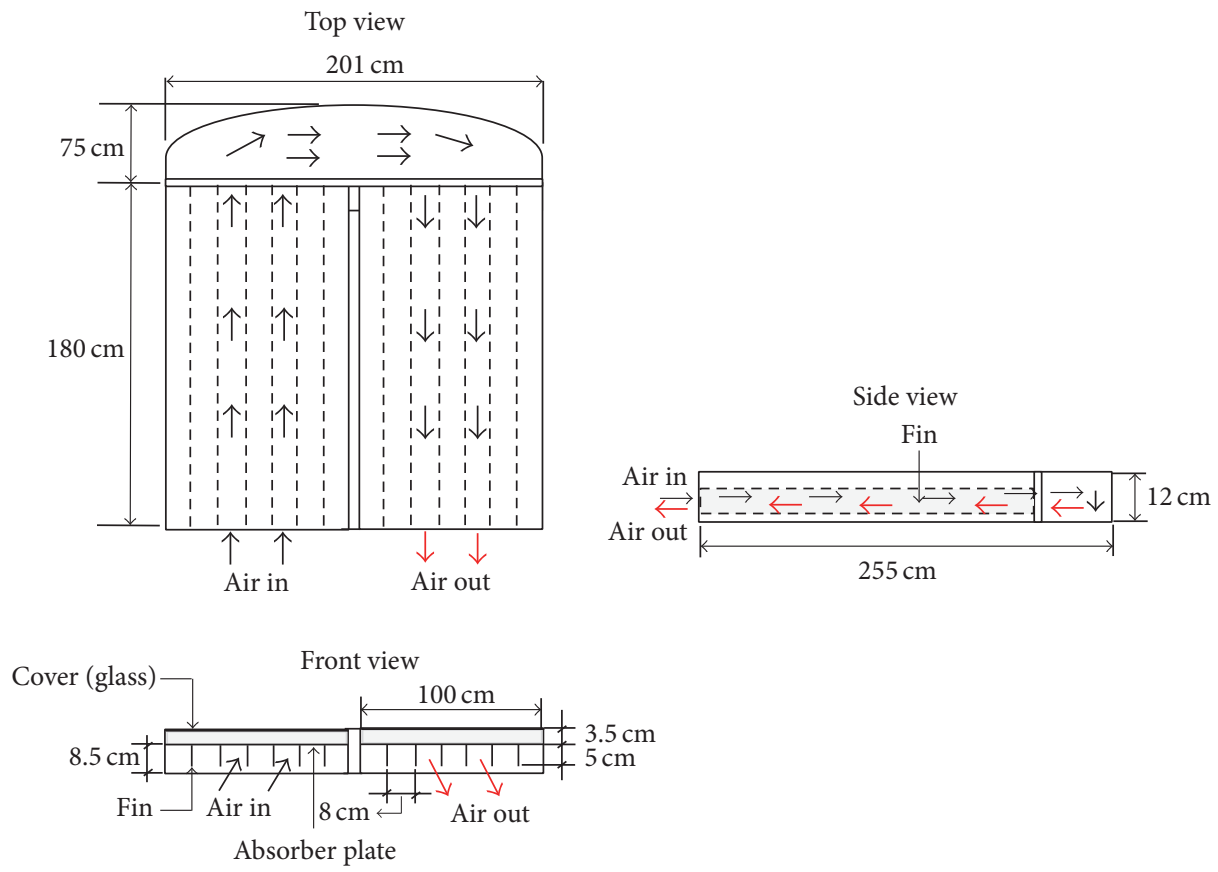

FIGURE 2: Dimensions of a single-pass solar collector with fin.

absorber plate finned used aluminum and black painted opaque, angle iron frame, inside and outside the collector coated with aluminum $1 \mathrm{~mm}$ thickness, and insulation using glass fiber materials. Two solar collectors are connected in series with an area of $1.8 \mathrm{~m}^{2}$ each, shown in Figure 2. The heat pump consists of several main parts: evaporator, condenser, compressor, and expansion valve. The working fluid of the heat pump is R-22. Compressor use of electrical capacity is $0.5 \mathrm{HP}$. The dimension of evaporator and condenser of the heat pump is shown in Figure 3. The biomass furnace consists of several main parts such as the combustion chamber, heat exchanger, chimney, and blower. The wall of the combustion chamber uses brick, cement, and steel plate materials and heat exchanger pipes using mild steel with diameter of 2 inc and the number of pipes is 16 units, in which dimension of biomass furnace is shown in Figure 4. The fluidized bed consists of several main parts such as drying chamber, air flow distribution, and the inlet and exit of paddy. The front part of the drying chamber is covered with clear glass with a thickness of $5 \mathrm{~mm}$, and the sides and back are covered with $3 \mathrm{~mm}$ thick aluminum plate, while the air distributor used wire aluminum gauze and dimensions as shown in Figure 5. Cyclone is covered with aluminum plate with $3 \mathrm{~mm}$ thickness, and its dimensions are shown in Figure 6. The drying air was circulated by using centrifugal blower (BFD) with $3.7 \mathrm{~kW}$ power (three phases).

2.2. Experimental Procedure. Experiments were performed at Padang Institute of Technology, West Sumatra, Indonesia. The samples of paddy were obtained from farmer in Padang and as much as $11 \mathrm{~kg}$ put into the drying chamber (bed depth of paddy of about $55 \mathrm{~cm}$ ) for the drying process. Biomass fuels used coconut shell charcoal. The drying experiments were performed to evaluate the dryer performance under two different operating modes: solar assisted fluidized bed dryer integrated biomass furnace (SA-FBDIBF) and solar assisted heat pump fluidized bed dryer integrated biomass furnace (SAHP-FBDIBF). Heat pump was not used for SA-FBDIBF 


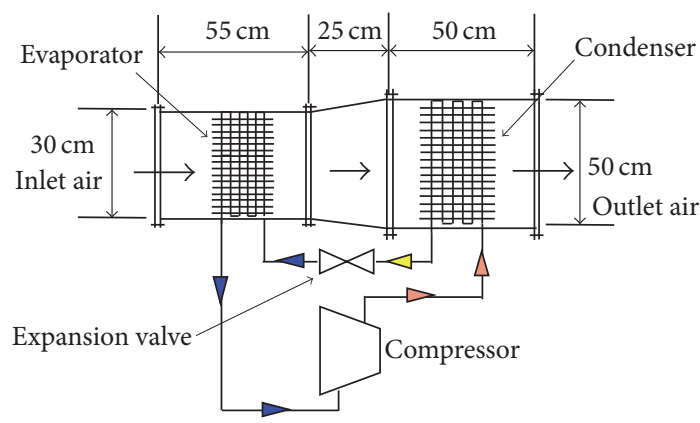

FIGURE 3: Dimensions of evaporator and condenser of heat pump.

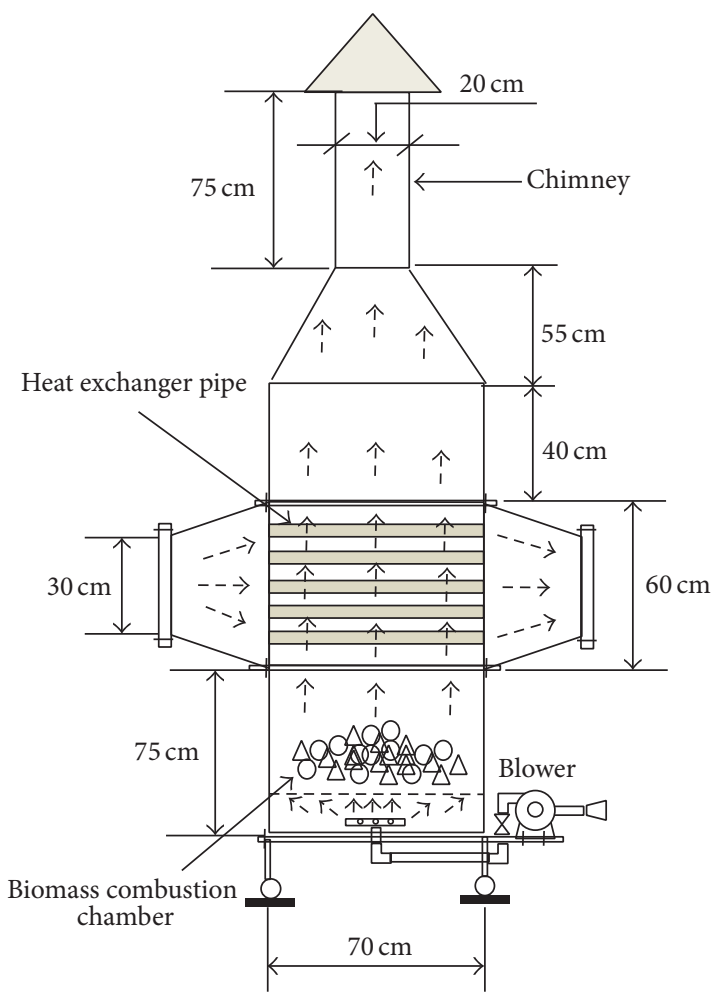

FIGURE 4: Dimensions of biomass furnace.

mode of operation as shown in Figure 7. Heat pump was employed for SAHP-FBDIBF mode of operation as shown in Figure 8.

The air temperatures at the inlet and outlet of the solar collector, heat pump, biomass furnace, and drying chamber during the operation of the drying system were measured by using $\mathrm{T}$ type copper-constantan thermocouples with an accuracy of $\pm 0.1^{\circ} \mathrm{C}$ and operating temperature range $\left(-200^{\circ} \mathrm{C}\right.$ to $400^{\circ} \mathrm{C}$ ). The solar radiation was measured by an LI-200 pyranometer in $\pm 0.1 \mathrm{Wm}^{-2}$ accuracy and with maximum solar radiation of $2000 \mathrm{Wm}^{-2}$, operating temperature range $\left(-40^{\circ} \mathrm{C}\right.$ to $\left.400^{\circ} \mathrm{C}\right)$, and operating relative humidity range $(0 \%$ to $100 \%$ ). The air velocity was measured with $0-30 \mathrm{~ms}^{-1}$ range of an HT-383 anemometer, an accuracy of $\pm 0.2 \mathrm{~ms}^{-1}$, and operation temperature range $\left(-10^{\circ} \mathrm{C}\right.$ to $\left.45^{\circ} \mathrm{C}\right)$. The air temperature and the solar radiation were recorded by an $\mathrm{AH} 4000$

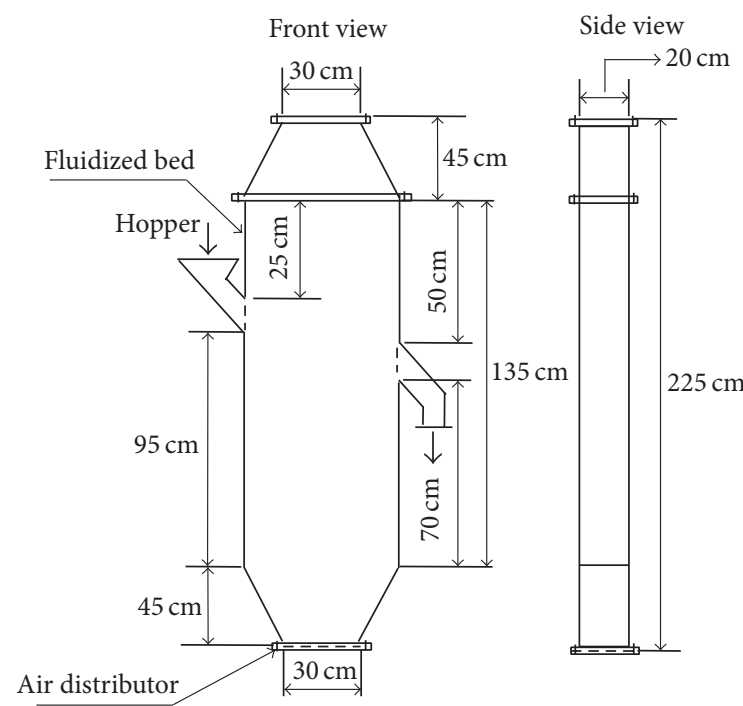

FIGURE 5: Dimensions of fluidized bed (drying chamber).

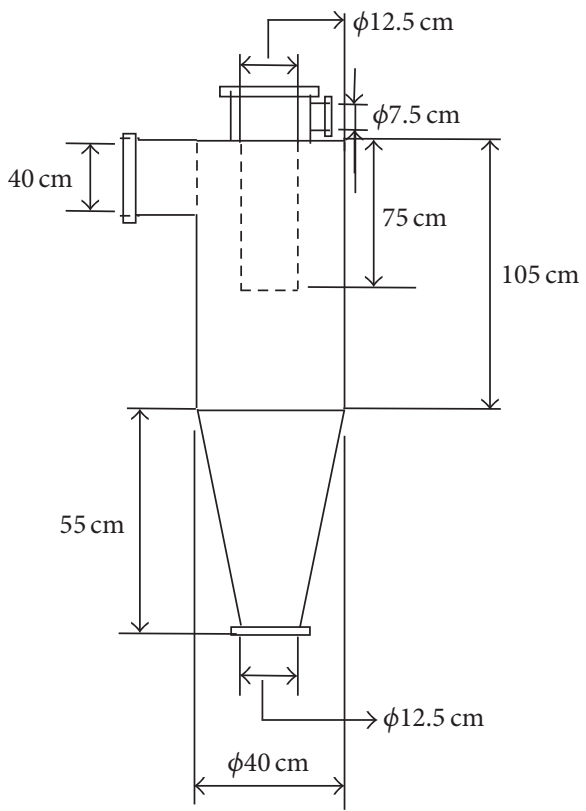

FIGURE 6: Dimensions of cyclone.

data logger with reading accuracy of $\pm 0.1^{\circ} \mathrm{C}$. The mass change of the paddy was measured within $0-15 \mathrm{~kg}$ range by using a TKB- 0.15 weighing scale, with an accuracy of $\pm 0.05 \mathrm{~kg}$. Paddy mass change was weighed and temperature was measured every 5 minutes. The uncertainty was calculated using the following equation $[19,20]$ :

$W_{R}$

$$
=\left[\left(\frac{\partial R}{\partial x_{1}} w_{1}\right)^{2}+\left(\frac{\partial R}{\partial x_{2}} w_{2}\right)^{2}+\cdots+\left(\frac{\partial R}{\partial x_{n}} w_{n}\right)^{2}\right]^{1 / 2},
$$




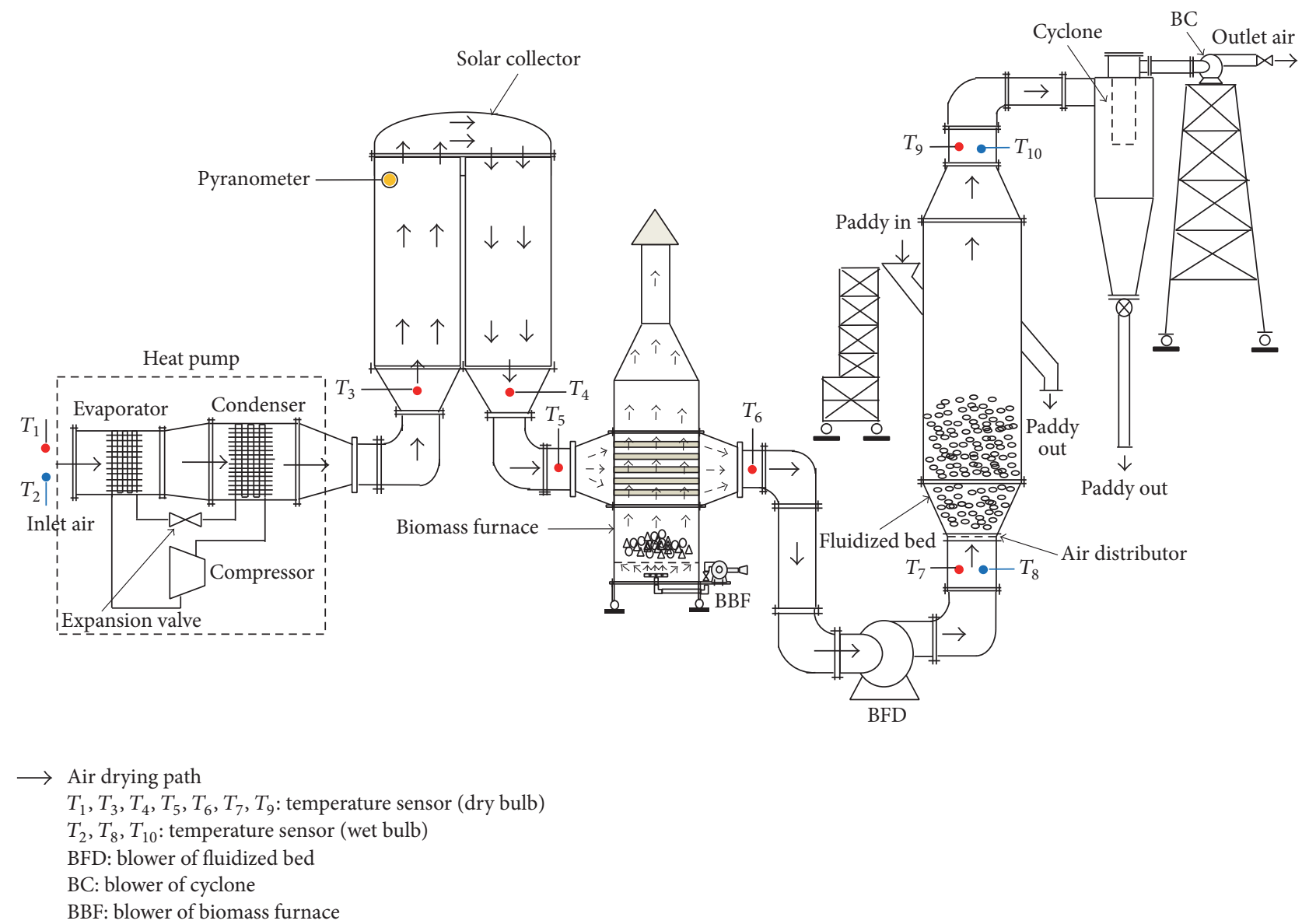

FIGURE 7: Schematic diagram of SA-FBDIBF (mode 1).

where $W_{R}$ is total uncertainty in result measurement, $w_{1}, w_{2}, \ldots, w_{n}$ are uncertainties in independent variables, and $x_{1}, x_{2}, \ldots, x_{n}$ are independent variables.

\subsection{Experimental Data Analysis}

2.3.1. Performance of Drying System. The performances of the solar assisted fluidized bed dryer integrated with biomass furnace (SA-FBDIBF) and the solar assisted heat pump fluidized bed dryer integrated with biomass furnace (SAHPFBDIBF) for drying of paddy may be characterized by variety of criteria, such as drying rate (DR), specific moisture extraction rate (SMER), specific energy consumption (SEC), specific thermal energy consumption (STEC), specific thermal energy consumption (SEEC), dryer thermal efficiency, and pickup efficiency. They were calculated using the following equations. During drying process, the moisture content of the paddy was calculated by two methods such as wet and dry basis using the following equations [21].

The moisture content wet basis was calculated as follows:

$$
M_{\mathrm{wb}}=\frac{m_{\text {wetp }}-m_{d}}{m_{\text {wetp }}} .
$$

The moisture content dry basis was calculated as follows:

$$
M_{\mathrm{db}}=\frac{m_{\mathrm{wetp}}-m_{d}}{m_{d}},
$$

where $m_{d}$ is the mass of bone dry of the paddy and $m_{\text {wetp }}$ is mass of wet paddy.

The drying rate is the mass of water evaporated from the wet paddy per unit time. It was calculated using the following equation [22]:

$$
\mathrm{DR}=\dot{m}_{\mathrm{water}}=\frac{m_{\mathrm{water}}}{t}=\frac{M_{\mathrm{db}, t}-M_{\mathrm{db}, t+\Delta t}}{\Delta t},
$$

where $M_{\mathrm{db}, t}$ is moisture content dry basis of paddy at the time " $t$, , $M_{\mathrm{db}, t+\Delta t}$ is moisture content dry basis of paddy at the time " $t+\Delta t, " m_{\text {water }}$ is the mass of water evaporated, $t$ is drying time, and $\Delta t$ is drying time interval.

The mass of the water evaporated $\left(m_{\text {water }}\right)$ from the wet paddy was calculated using the following equation [23]:

$$
m_{\mathrm{water}}=\frac{m_{\mathrm{wetp}}\left(M_{\mathrm{wb}, i}-M_{\mathrm{wb}, f}\right)}{\left(100-M_{\mathrm{wb}, f}\right)} \text {, }
$$



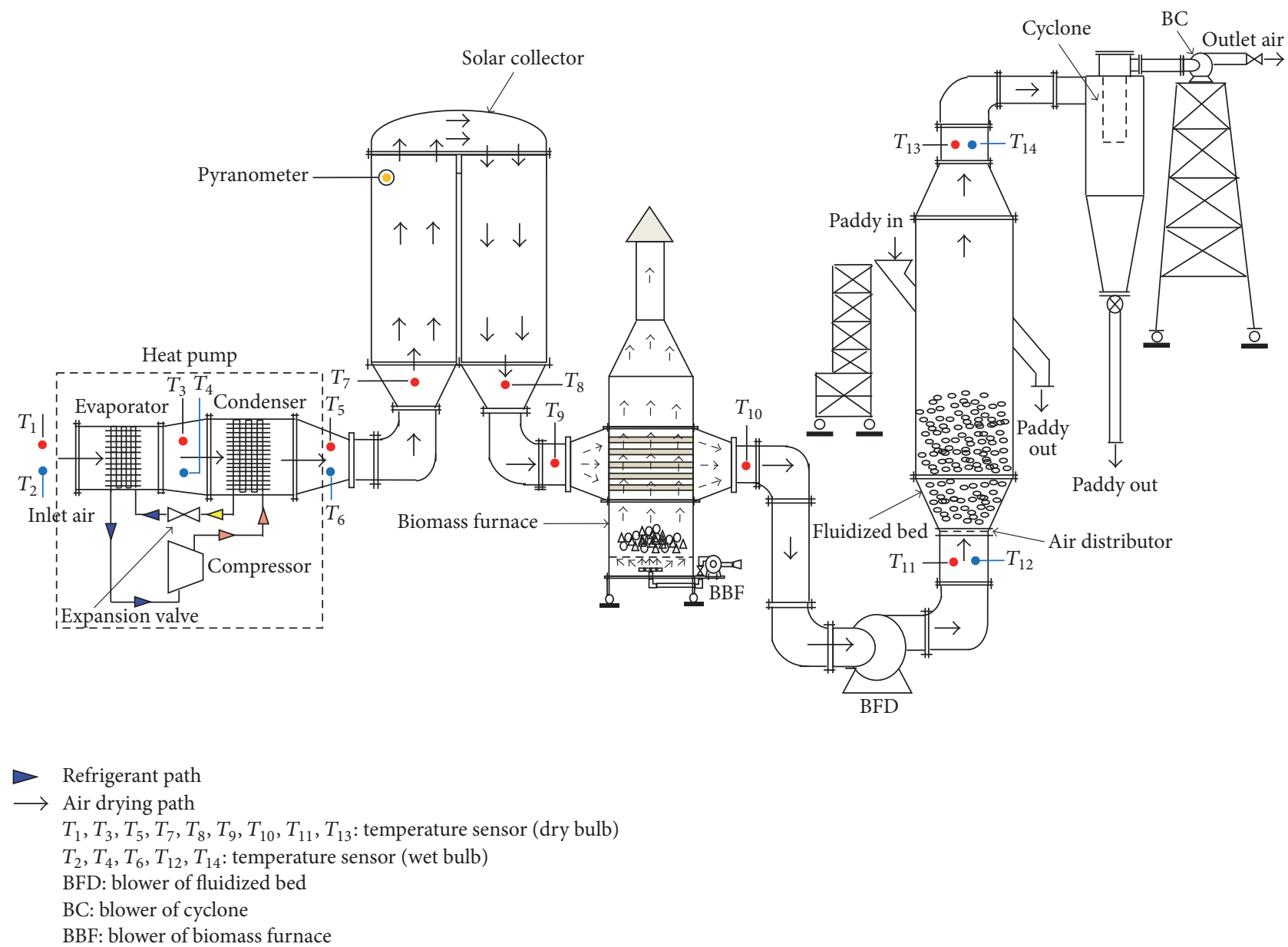

Figure 8: Schematic diagram of SAHP-FBDIBF (mode 2).

where $m_{\text {wetp }}$ is initial mass of wet paddy, $M_{\mathrm{wb}, i}$ is initial moisture content on wet basis, and $M_{\mathrm{wb}, f}$ is final moisture content on the wet basis.

Specific moisture extraction rate (SMER) is ratio of the moisture evaporated from wet product to the energy input to drying system. The specific moisture extraction rates of the SA-FBDIBF and the SAHP-FBDIBF were calculated using the following equations [24].

The SMER for the SA-FBDIBF:

$$
\begin{aligned}
& \text { SMER }_{\text {SA-FBDIBF }} \\
& =\frac{\dot{m}_{\text {water }}}{I_{T} A_{\mathrm{SC}}+\dot{m}_{\mathrm{bmf}} \mathrm{CV}_{\mathrm{bmf}}+W_{\mathrm{BFD}}+W_{\mathrm{BC}}} .
\end{aligned}
$$

The SMER for the SAHP-FBDIBF:

$$
\begin{aligned}
& \text { SMER }_{\text {SAHP-FBDIBF }} \\
& =\frac{\dot{m}_{\text {water }}}{I_{T} A_{\mathrm{SC}}+\dot{m}_{\mathrm{bmf}} C V_{\mathrm{bmf}}+W_{\mathrm{Comp}}+W_{\mathrm{BFD}}+W_{\mathrm{BC}}},
\end{aligned}
$$

where $W_{\mathrm{BFD}}$ is the electrical energy consumed by blower of fluidized bed and $W_{\mathrm{BC}}$ is the electrical energy consumed by blower of cyclone.
The electrical energies consumed by compressor and blower of cyclone were calculated using the following equation [25]:

$$
W_{\text {Comp }}, W_{\mathrm{BC}}=V I \cos \varphi \quad(\text { Single phase })
$$

The electrical energy consumed by blower of fluidized bed was calculated using the following equation:

$$
W_{\mathrm{BFD}}=\sqrt{3} V I \cos \varphi \quad(\text { Three phase })
$$

where $V$ is the line voltage, $I$ is the line current, and $\cos \varphi$ is the power factor.

Specific energy consumption (SEC) is the measure of the energy used to remove $1 \mathrm{~kg}$ of water in the drying process. The specific energy consumption of the SA-FBDIBF and the SAHP-FBDIBF was calculated using the following equations [26].

The SEC for the SA-FBDIBF:

$$
\mathrm{SEC}_{\mathrm{SA}-\mathrm{FBDIBF}}=\frac{I_{T} A_{\mathrm{SC}}+\dot{m}_{\mathrm{bmf}} \mathrm{CV}_{\mathrm{bmf}}+W_{\mathrm{BFD}}+W_{\mathrm{BC}}}{\dot{m}_{\text {water }}} .
$$


The SEC for the SAHP-FBDIBF:

$$
\begin{aligned}
& \mathrm{SEC}_{\mathrm{SAHP}-\mathrm{FBDIBF}} \\
& \quad=\frac{I_{T} A_{\mathrm{SC}}+\dot{m}_{\mathrm{bmf}} \mathrm{CV}_{\mathrm{bmf}}+W_{\mathrm{Comp}}+W_{\mathrm{BFD}}+W_{\mathrm{BC}}}{\dot{m}_{\text {water }}} .
\end{aligned}
$$

The specific thermal energy consumption (STEC) of the SA-FBDIBF and the SAHP-FBDIBF was calculated using the following equations [27].

The STEC for the SA-FBDIBF:

$$
\mathrm{STEC}_{\mathrm{SA}-\mathrm{FBDIBF}}=\frac{I_{T} A_{\mathrm{SC}}+\dot{m}_{\mathrm{bmf}} \mathrm{CV}_{\mathrm{bmf}}}{\dot{m}_{\text {water }}} .
$$

The STEC for the SAHP-FBDIBF:

$$
\mathrm{STEC}_{\mathrm{SAHP}-\mathrm{FBDIBF}}=\frac{I_{T} A_{\mathrm{SC}}+\dot{m}_{\mathrm{bmf}} \mathrm{CV}_{\mathrm{bmf}}+W_{\mathrm{Comp}}}{\dot{m}_{\text {water }}} .
$$

The specific electrical energy consumption (SEEC) of the SA-FBDIBF and the SAHP-FBDIBF was calculated using the following equations [28].

The SEEC for the SA-FBDIBF:

$$
\operatorname{SEEC}_{\mathrm{SA}-\mathrm{FBDIBF}}=\frac{W_{\mathrm{BFD}}+W_{\mathrm{BC}}}{\dot{m}_{\text {water }}} .
$$

The SEEC for the SAHP-FBDIBF:

$$
\mathrm{SEEC}_{\mathrm{SAHP}-\mathrm{FBDIBF}}=\frac{W_{\text {Comp }}+W_{\mathrm{BFD}}+W_{\mathrm{BC}}}{\dot{m}_{\text {water }}} .
$$

Thermal efficiency of drying system is ratio of the energy used for moisture evaporation to the energy input to drying system. The thermal efficiency of the SA-FBDIBF and the SAHP-FBDIBF was calculated using the following equations [29].

The thermal efficiency of the SA-FBDIBF:

$$
\eta_{\mathrm{th}, \mathrm{SA}-\mathrm{FBDIBF}}=\frac{\dot{m}_{\mathrm{water}} H_{f g}}{I_{T} A_{\mathrm{SC}}+\dot{m}_{\mathrm{bmf}} \mathrm{CV}_{\mathrm{bmf}}+W_{\mathrm{BFD}}+W_{\mathrm{BC}}} .
$$

The thermal efficiency of the SAHP-FBDIBF:

$$
\begin{aligned}
& \eta_{\text {th,SAHP-FBDIBF }} \\
& \quad=\frac{\dot{m}_{\text {water }} H_{f g}}{I_{T} A_{\mathrm{SC}}+\dot{m}_{\mathrm{bmf}} \mathrm{CV}_{\mathrm{bmf}}+W_{\mathrm{Comp}}+W_{\mathrm{BFD}}+W_{\mathrm{BC}}},
\end{aligned}
$$

where $H_{f g}$ is latent heat of vapourization of water $(\mathrm{kJ} / \mathrm{kg})$.

Pickup efficiency is the ratio of the moisture evaporated from wet product or the moisture picked up by the air in the drying chamber to the theoretical capacity of the air to absorb moisture. The pickup efficiency of the SA-FBDIBF and the
SAHP-FBDIBF was calculated using the following equation [9]:

$$
\eta_{\text {Pickup }}=\frac{m_{\text {water }}}{\dot{m}_{\mathrm{da}} t\left(Y_{\text {as }}-Y_{i}\right)},
$$

where $\dot{m}_{\mathrm{da}}$ is mass flow rate of dry air $\left(\mathrm{kg}_{\text {dry air }} / \mathrm{s}\right)$, $Y_{i}$ is absolute humidity of air entering drying chamber $\left(\mathrm{kg}_{\text {water }} / \mathrm{kg}_{\text {dry air }}\right)$, and $Y_{\text {as }}$ is adiabatic saturation humidity of air entering drying chamber $\left(\mathrm{kg}_{\text {water }} / \mathrm{kg}_{\text {dry air }}\right)$.

The performance of drying system is satisfactorily depending on the performance of each of the drying system components such as solar collector, heat pump, and biomass furnace. The thermal efficiency of a solar collector is the ratio of useful heat gain by solar collector to the energy incident in the plane of the collector. It was calculated using the following equation [30]:

$$
\eta_{\text {coll }}=\frac{\dot{m}_{\mathrm{air}} C_{P_{\mathrm{air}}}\left(T_{\mathrm{out}, \mathrm{SC}}-T_{\mathrm{in}, \mathrm{SC}}\right)}{I_{T} A_{\mathrm{SC}}} \times 100 \%,
$$

where $\dot{m}_{\text {air }}$ is air mass flow rate, $C_{P_{\text {air }}}$ is specific heat of air, and $T_{\mathrm{in}, \mathrm{SC}}$ and $T_{\text {out,SC}}$ are inlet and outlet air temperatures of solar collector, respectively. $A_{\mathrm{SC}}$ is an area of collector and $I_{T}$ is solar radiation incident in the collector.

The coefficient of performance of a heat pump (COP) is the ratio of useful heat or heat energy released by the refrigerant in the condenser to the electrical energy consumed by compressor. It was calculated using the following equation [31]:

$$
\mathrm{COP}_{\mathrm{hp}}=\frac{\dot{m}_{\mathrm{air}} C_{P_{\mathrm{air}}}\left(T_{\mathrm{out}, \mathrm{Cond}}-T_{\mathrm{in}, \mathrm{Cond}}\right)}{W_{\text {Comp }}},
$$

where $T_{\mathrm{in}, \text { Cond }}$ and $T_{\text {out,Cond }}$ are inlet and outlet air temperatures of condenser, respectively, and $W_{\text {Comp }}$ is the electrical energy consumed by the compressor.

The thermal efficiency of a biomass furnace is the ratio of useful heat by biomass furnace to the heat energy generated by the combustion of the biomass fuel. It was calculated using the following equation [32]:

$$
\eta_{\mathrm{BF}}=\frac{\dot{m}_{\mathrm{air}} C_{P_{\mathrm{air}}}\left(T_{\mathrm{out}, \mathrm{BF}}-T_{\mathrm{in}, \mathrm{BF}}\right)}{\dot{m}_{\mathrm{bmf}} C V_{\mathrm{bmf}}} \times 100 \%,
$$

where $T_{\mathrm{in}, \mathrm{BF}}$ and $T_{\text {out,BF }}$ are the inlet and outlet air temperatures of biomass furnace, respectively, $\dot{m}_{\mathrm{bmf}}$ is biomass fuel consumption rate, and $\mathrm{CV}_{\mathrm{bmf}}$ is caloric value of biomass fuel. The biomass fuel uses coconut shell charcoal with a caloric value of about $7600 \mathrm{kcal} / \mathrm{kg}$ [33].

Solar energy and biomass fuel energy fractions are defined by energy supplied by solar collector and biomass furnace parts of a drying system divided by the total drying system load. The solar energy and biomass fuel energy fractions of the SA-FBDIBF and the SAHP-FBDIBF were calculated using the following equations [34].

The solar energy fraction for the SA-FBDIBF:

$$
\begin{aligned}
f_{\mathrm{SE}, \mathrm{SA}-\mathrm{FBDIBF}}= & \frac{\dot{m}_{\mathrm{air}} C_{P_{\mathrm{air}}}\left(T_{\mathrm{out}, \mathrm{SC}}-T_{\mathrm{in}, \mathrm{SC}}\right)}{I_{T} A_{\mathrm{SC}}+\dot{m}_{\mathrm{bmf}} \mathrm{CV}_{\mathrm{bmf}}+W_{\mathrm{BFD}}+W_{\mathrm{BC}}} \\
& \times 100 .
\end{aligned}
$$


TABLE 1: Mathematical models used for drying curves [38-43].

\begin{tabular}{lc}
\hline Model name & Model \\
\hline Newton & $\mathrm{MR}=\exp (-k t)$ \\
Henderson and Pabis & $\mathrm{MR}=a \exp (-k t)$ \\
Page & $\mathrm{MR}=\exp \left(-k t^{n}\right)$ \\
\hline
\end{tabular}

The solar energy fraction for the SAHP-FBDIBF:

$$
\begin{aligned}
& =\frac{\dot{m}_{\mathrm{air}} C_{P_{\mathrm{air}}}\left(T_{\mathrm{out}, \mathrm{SC}}-T_{\mathrm{in}, \mathrm{SC}}\right)}{I_{T} A_{\mathrm{SC}}+\dot{m}_{\mathrm{bmf}} \mathrm{CV}_{\mathrm{bmf}}+W_{\mathrm{Comp}}+W_{\mathrm{BFD}}+W_{\mathrm{BC}}} \\
& \times 100 \% \text {. }
\end{aligned}
$$

The biomass fuel energy fraction for the SA-FBDIBF:

$$
\begin{aligned}
f_{\mathrm{bmf}, \mathrm{SA}-\mathrm{FBDIBF}}= & \frac{\dot{m}_{\mathrm{air}} C_{P_{\mathrm{air}}}\left(T_{\mathrm{out}, \mathrm{BF}}-T_{\mathrm{in}, \mathrm{BF}}\right)}{I_{T} A_{\mathrm{SC}}+\dot{m}_{\mathrm{bmf}} \mathrm{C} V_{\mathrm{bmf}}+W_{\mathrm{BFD}}+W_{\mathrm{BC}}} \\
& \times 100 \% .
\end{aligned}
$$

The biomass fuel energy fraction for the SAHPFBDIBF:

$$
\begin{aligned}
& f_{\text {bmf,SAHP-FBDIBF }} \\
& =\frac{\dot{m}_{\mathrm{air}} C_{P_{\mathrm{air}}}\left(T_{\mathrm{out}, \mathrm{BF}}-T_{\mathrm{in}, \mathrm{BF}}\right)}{I_{T} A_{\mathrm{SC}}+\dot{m}_{\mathrm{bmf}} \mathrm{CV}_{\mathrm{bmf}}+W_{\mathrm{Comp}}+W_{\mathrm{BFD}}+W_{\mathrm{BC}}} \\
& \times 100 \% \text {. }
\end{aligned}
$$

2.3.2. Mathematical Modelling of Drying Curves. The experimental dimensionless moisture content data obtained were fitted to the three best drying models given in Table 1. The dimensionless moisture content data was estimated as follows [35]:

$$
\mathrm{MR}=\frac{\left(M_{t}-M_{e}\right)}{\left(M_{o}-M_{e}\right)}
$$

where $\mathrm{MR}$ is the dimensionless moisture content and $M_{e}$, $M_{o}$, and $M_{t}$ are the equilibrium moisture content, the initial moisture content, and the moisture content at any time in dry basis, respectively; because of the continuous fluctuation of the relative humidity of the drying air during their drying processes the dimensionless moisture content (MR) was simplified to the following equation [36]:

$$
\mathrm{MR}=\frac{M_{t}}{M_{o}}
$$

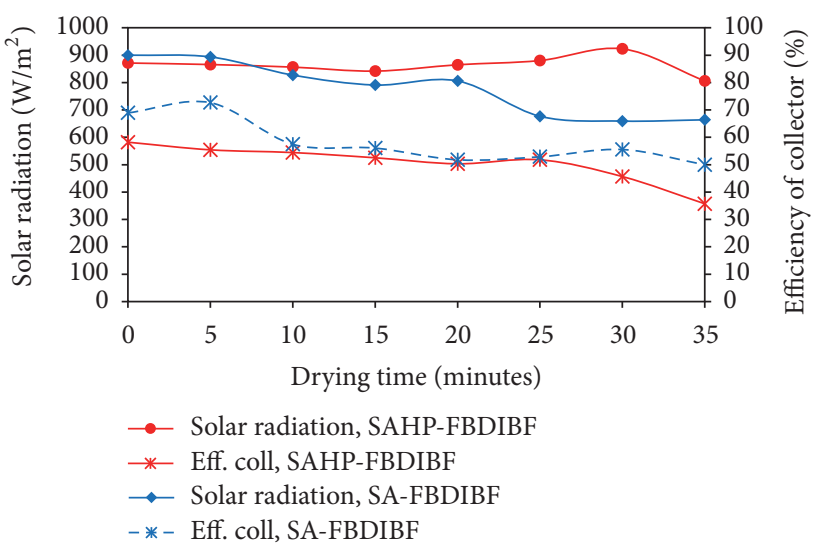

FIGURE 9: The variation of solar radiation and efficiency of collector with drying time.

The correlation coefficient $\left(R^{2}\right)$, mean bias error (MBE), and root mean-square error (RMSE) obtained for these mathematical models were used to analyze the relative goodness of the fit. These parameters were calculated as follows [37]:

$$
\begin{aligned}
\mathrm{MBE} & =\frac{1}{N} \sum_{i=1}^{N}\left(\mathrm{MR}_{\mathrm{pre}, i}-\mathrm{MR}_{\exp , i}\right)^{2}, \\
\mathrm{RMSE} & =\left[\frac{1}{N} \sum_{i=1}^{N}\left(\mathrm{MR}_{\mathrm{pre}, i}-\mathrm{MR}_{\exp , i}\right)^{2}\right]^{1 / 2},
\end{aligned}
$$

where $\mathrm{MR}_{\exp , i}$ is the $i$ th experimental dimensionless moisture content, $\mathrm{MR}_{\mathrm{pre}, i}$ is the $i$ th predicted dimensionless moisture content, $N$ is the number of observations, and $n$ is the number constant.

\section{Results and Discussion}

The variations of solar radiation and collector efficiency with drying time for solar assisted heat pump fluidized bed dryer integrated biomass furnace (SAHP-FBDIBF) and solar assisted fluidized bed dryer integrated biomass furnace (SAFBDIBF) are shown in Figure 9. For the SA-FBDIBF, the solar radiation was recorded in the range of $659.2 \mathrm{Wm}^{-2}-$ $900.8 \mathrm{Wm}^{-2}$, with an average value of $777.2 \mathrm{Wm}^{-2}$. For the SAHP-FBDIBF, the solar radiation was recorded in the range of $805.9 \mathrm{Wm}^{-2}-923.2 \mathrm{Wm}^{-2}$, with an average value of $863.8 \mathrm{Wm}^{-2}$, whereas the collector efficiencies were calculated in the range of $30.01 \%-72.69 \%$ and $35.72 \%-58.51 \%$, with average values of 58.20 and $50.51 \%$ for SA-FBDIBF and SAHP-FBDIBF, respectively, under an air mass flow rate of $0.1037 \mathrm{kgs}^{-1}$. The evaluation of the uncertainty of dryer performance is presented in Table 2.

The variations of temperature and relative humidity at inlet and outlet of heat pump with drying time for SAHPFBDIBF are shown in Figure 10. The temperatures at inlet and outlet of the heat pump were in the range of $35.1^{\circ} \mathrm{C}-$ $37.0^{\circ} \mathrm{C}$ and $40.4^{\circ} \mathrm{C}-42.0^{\circ} \mathrm{C}$, with average values of $36.0^{\circ} \mathrm{C}$ and $41.3^{\circ} \mathrm{C}$, respectively, whereas the relative humidity at inlet and outlet of the heat pump was in the range of $53.7 \%-64.4 \%$ 
TABLE 2: Uncertainties of the parameters during drying experiment of paddy.

\begin{tabular}{|c|c|c|c|}
\hline \multirow[b]{2}{*}{ Parameters } & \multirow[b]{2}{*}{ Unit } & \multicolumn{2}{|c|}{ Uncertainty comment } \\
\hline & & $\begin{array}{l}\text { SA- } \\
\text { FBDIBF }\end{array}$ & $\begin{array}{l}\text { SAHP- } \\
\text { FBDIBF }\end{array}$ \\
\hline Ambient air temperature & ${ }^{\circ} \mathrm{C}$ & \pm 0.17 & \pm 0.17 \\
\hline $\begin{array}{l}\text { Inlet air temperature of heat } \\
\text { pump }\end{array}$ & ${ }^{\circ} \mathrm{C}$ & - & \pm 0.17 \\
\hline $\begin{array}{l}\text { Outlet air temperature of } \\
\text { heat pump }\end{array}$ & ${ }^{\circ} \mathrm{C}$ & - & \pm 0.17 \\
\hline $\begin{array}{l}\text { Inlet air temperature of } \\
\text { condenser }\end{array}$ & ${ }^{\circ} \mathrm{C}$ & - & \pm 0.17 \\
\hline $\begin{array}{l}\text { Outlet air temperature of } \\
\text { condenser }\end{array}$ & ${ }^{\circ} \mathrm{C}$ & - & \pm 0.17 \\
\hline $\begin{array}{l}\text { Inlet air temperature of solar } \\
\text { collector }\end{array}$ & ${ }^{\circ} \mathrm{C}$ & \pm 0.17 & \pm 0.17 \\
\hline $\begin{array}{l}\text { Outlet air temperature of } \\
\text { solar collector }\end{array}$ & ${ }^{\circ} \mathrm{C}$ & \pm 0.17 & \pm 0.17 \\
\hline $\begin{array}{l}\text { Inlet air temperature of } \\
\text { biomass furnace }\end{array}$ & ${ }^{\circ} \mathrm{C}$ & \pm 0.17 & \pm 0.17 \\
\hline $\begin{array}{l}\text { Outlet air temperature of } \\
\text { biomass furnace }\end{array}$ & ${ }^{\circ} \mathrm{C}$ & \pm 0.17 & \pm 0.17 \\
\hline $\begin{array}{l}\text { Inlet air temperature of } \\
\text { drying chamber }\end{array}$ & ${ }^{\circ} \mathrm{C}$ & \pm 0.17 & \pm 0.17 \\
\hline $\begin{array}{l}\text { Outlet air temperature of } \\
\text { drying chamber }\end{array}$ & ${ }^{\circ} \mathrm{C}$ & \pm 0.17 & \pm 0.17 \\
\hline $\begin{array}{l}\text { Ambient air relative } \\
\text { humidity }\end{array}$ & $\%$ & \pm 0.22 & \pm 0.22 \\
\hline $\begin{array}{l}\text { Inlet air relative humidity of } \\
\text { heat pump }\end{array}$ & $\%$ & - & \pm 0.22 \\
\hline $\begin{array}{l}\text { Outlet air relative humidity } \\
\text { of heat pump }\end{array}$ & $\%$ & - & \pm 0.22 \\
\hline $\begin{array}{l}\text { Inlet air relative humidity of } \\
\text { drying chamber }\end{array}$ & $\%$ & \pm 0.22 & \pm 0.22 \\
\hline $\begin{array}{l}\text { Outlet air relative humidity } \\
\text { of drying chamber }\end{array}$ & $\%$ & \pm 0.22 & \pm 0.22 \\
\hline $\begin{array}{l}\text { Inlet air absolute humidity of } \\
\text { drying chamber }\end{array}$ & $\begin{array}{l}\text { kg water/ } \\
\text { kg dry air }\end{array}$ & \pm 0.26 & \pm 0.26 \\
\hline $\begin{array}{l}\text { Inlet air adiabatic saturation } \\
\text { humidity of drying chamber }\end{array}$ & $\begin{array}{l}\text { kg water/ } \\
\text { kg dry air }\end{array}$ & \pm 0.26 & \pm 0.26 \\
\hline Solar radiation & $\mathrm{W} / \mathrm{m}^{2}$ & \pm 0.14 & \pm 0.14 \\
\hline Air velocity & $\mathrm{m} / \mathrm{s}$ & \pm 0.24 & \pm 0.24 \\
\hline Mass loss of samples & g & \pm 0.014 & \pm 0.014 \\
\hline Mass loss of products & $\mathrm{kg}$ & \pm 0.11 & \pm 0.11 \\
\hline $\begin{array}{l}\text { Reading values of table ( } \rho \text {, } \\
\left.C_{P_{\text {air }}}, \mathrm{CV} \text {, and } H_{f g}\right)\end{array}$ & - & $\pm 0.1-0.2$ & $\pm 0.1-0.2$ \\
\hline Time measurement & $\min$ & \pm 0.1 & \pm 0.1 \\
\hline
\end{tabular}

and $39.8 \%-44.1 \%$, with average values of $58.1 \%$ and $41.6 \%$, respectively. The heat pump can increase the temperature and decrease relative humidity with average values of $5.2^{\circ} \mathrm{C}$ and $16.5 \%$, respectively.

The variations of temperature at inlet and outlet of condenser and COP of the heat pump with drying time for SAHP-FBDIBF are shown in Figure 11. The temperature at inlet and outlet of the condenser ranged from $27.0^{\circ} \mathrm{C}$ to $29.8^{\circ} \mathrm{C}$ and $40.4^{\circ} \mathrm{C}$ to $42.0^{\circ} \mathrm{C}$, with average values of $27.9^{\circ} \mathrm{C}$ and $41.3^{\circ} \mathrm{C}$, respectively, whereas the $\mathrm{COP}$ of the heat pump was

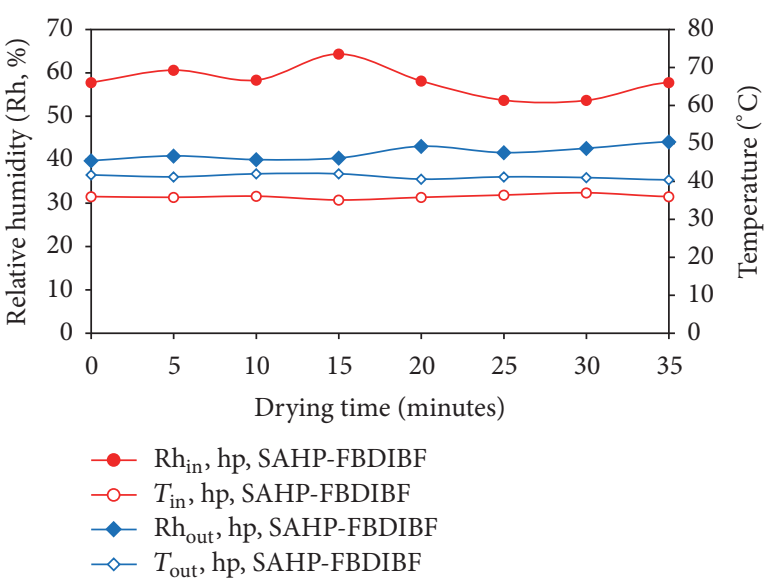

FIGURE 10: The variation of air temperature and relative humidity with drying time for SAHP-FBDIBF.

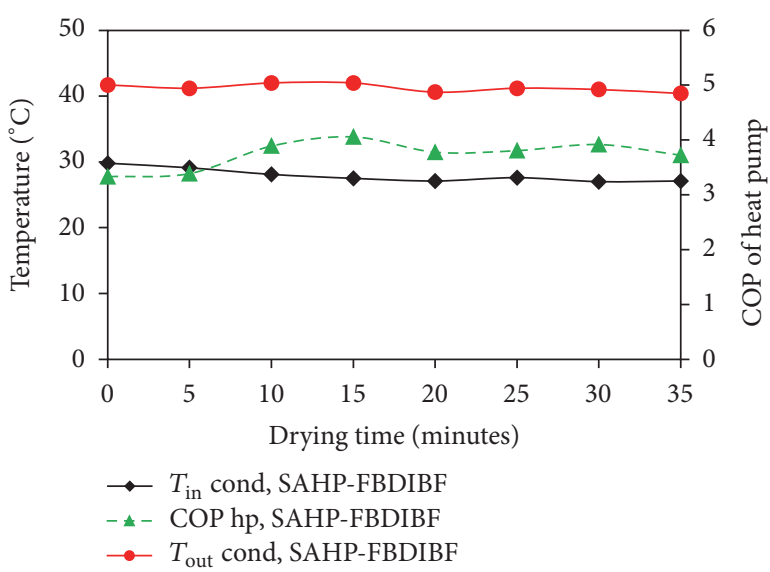

FIGURE 11: The variation of temperature and COP of heat pump with drying time for SAHP-FBDIBF.

calculated in the range of 3.33-4.06, with an average value of 3.74 , respectively, under an air mass flow rate of $0.10369 \mathrm{kgs}^{-1}$.

The variation of temperature at inlet and outlet of biomass furnace and efficiency of biomass furnace with drying time for SAHP-FBDIBF and SA-FBDIBF are shown in Figure 12. For the SA-FBDIBF, the temperature at inlet and outlet of the biomass furnace ranged from $39.1^{\circ} \mathrm{C}$ to $51.4^{\circ} \mathrm{C}$ and $83.8^{\circ} \mathrm{C}$ to $88.7^{\circ} \mathrm{C}$, with average values of $44.5^{\circ} \mathrm{C}$ and $86.7^{\circ} \mathrm{C}$, respectively. For the SAHP-FBDIBF, the temperatures at inlet and outlet of the biomass furnace were in the range of $46.5^{\circ} \mathrm{C}-51.2^{\circ} \mathrm{C}$ and $83.6^{\circ} \mathrm{C}-88.2^{\circ} \mathrm{C}$, with average values of $49.8^{\circ} \mathrm{C}$ and $85.9^{\circ} \mathrm{C}$, respectively, whereas the efficiencies of the biomass furnace were calculated in the range of $65.14 \%-86.44 \%$ and $71.33 \%-$ $80.36 \%$, with average values of $75.57 \%$ and $77.49 \%$ for SAFBDIBF and SAHP-FBDIBF, respectively, under an air mass flow rate of $0.1037 \mathrm{kgs}^{-1}$.

The variation of temperature and relative humidity at inlet and outlet of drying chamber (fluidized bed) with drying time for SAHP-FBDIBF and SA-FBDIBF are shown in Figures 13 and 14. Figure 13 shows the variation of temperature at inlet and outlet of drying chamber with drying time. 


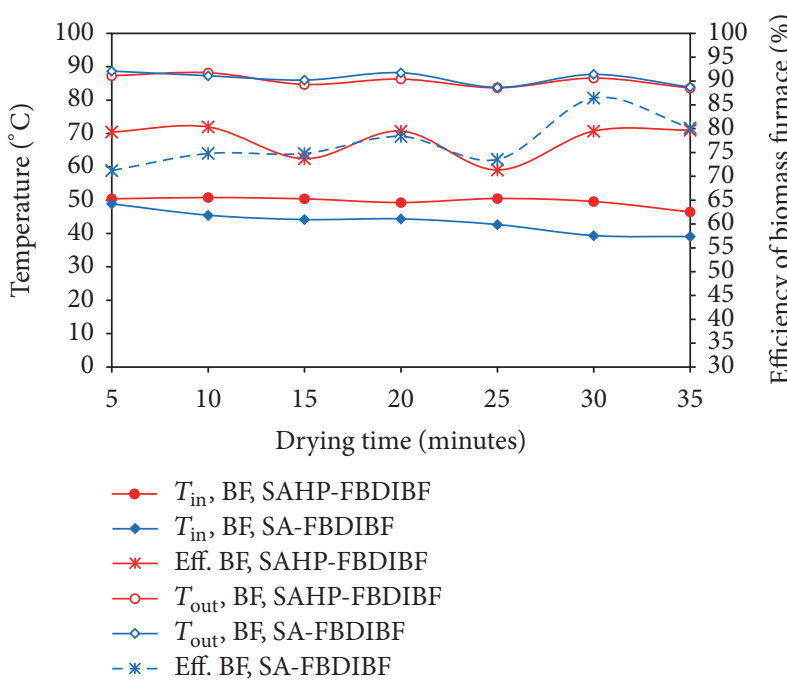

FIGURE 12: The variation of temperature and efficiency of biomass furnace with drying time.

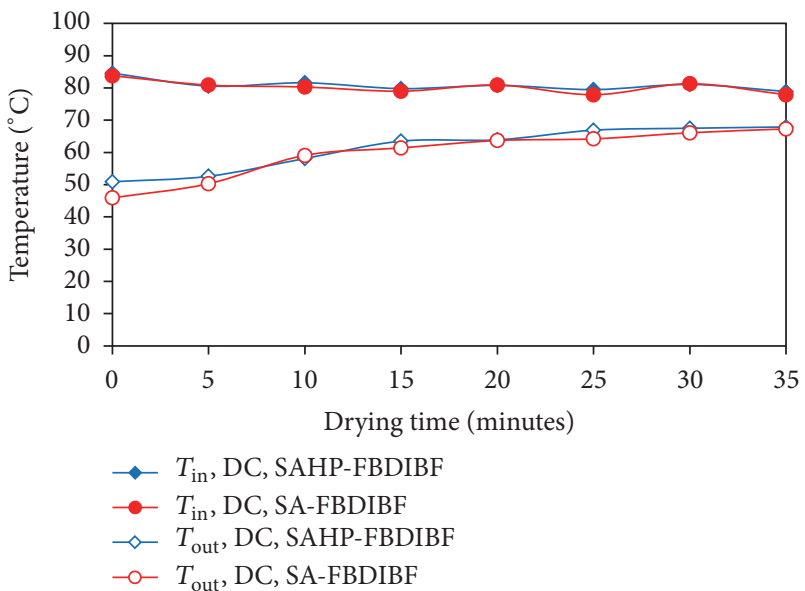

FIGURE 13: The variation of temperature with drying time.

For the SA-FBDIBF, the temperatures at inlet and outlet of drying chamber were recorded in the range of $77.9^{\circ} \mathrm{C}-$ $83.8^{\circ} \mathrm{C}$ and $45.9^{\circ} \mathrm{C}-67.3^{\circ} \mathrm{C}$, with average values of $80.3^{\circ} \mathrm{C}$ and $59.8^{\circ} \mathrm{C}$, respectively, whereas, for the SAHP-FBDIBF, the temperatures at inlet and outlet of the drying chamber were recorded in the range of $78.9^{\circ} \mathrm{C}-81.6^{\circ} \mathrm{C}$ and $50.9^{\circ} \mathrm{C}-$ $67.9^{\circ} \mathrm{C}$, with average values of $80.9^{\circ} \mathrm{C}$ and $61.4^{\circ} \mathrm{C}$, respectively. Figure 14 shows the variation of relative humidity at inlet and outlet of drying chamber with drying time. For the SA-FBDIBF, the relative humidity at inlet and outlet of the drying chamber ranged from $10.85 \%$ to $13.12 \%$ and $15.7 \%$ to $48.3 \%$, with average values of $12.28 \%$ and $24.3 \%$, respectively, whereas, for the SAHP-FBDIBF, the relative humidity at inlet and outlet of the drying chamber ranged from $6.91 \%$ to $8.74 \%$ and $17.8 \%$ to $53.2 \%$, with average values of $8.14 \%$ and $27.5 \%$, respectively. As seen from Figures 13 and 14 the temperature and relative humidity at outlet of drying chamber increased and decreased with increasing in drying time. These, due to the heat transfer coefficient and the mass transfer coefficient,

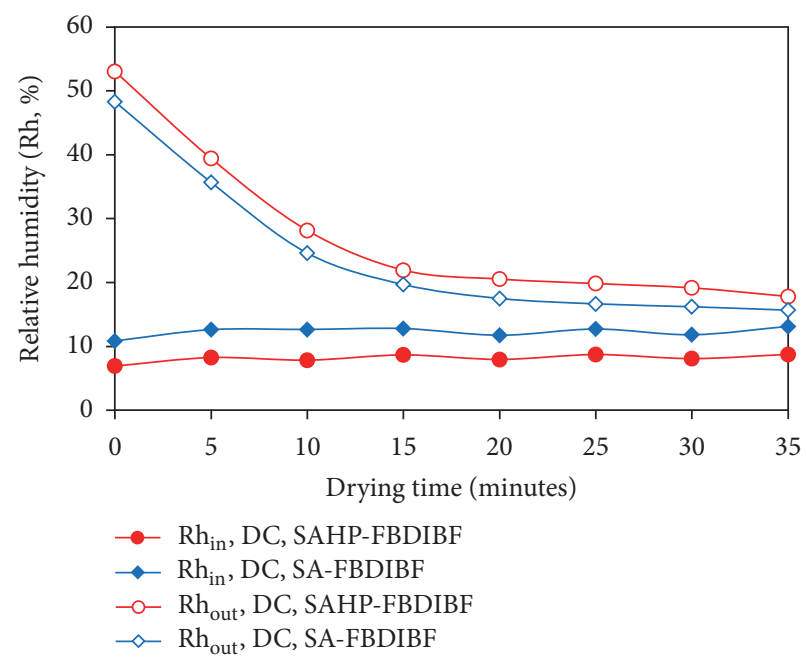

FIGURE 14: The variation of relative humidity with drying time.

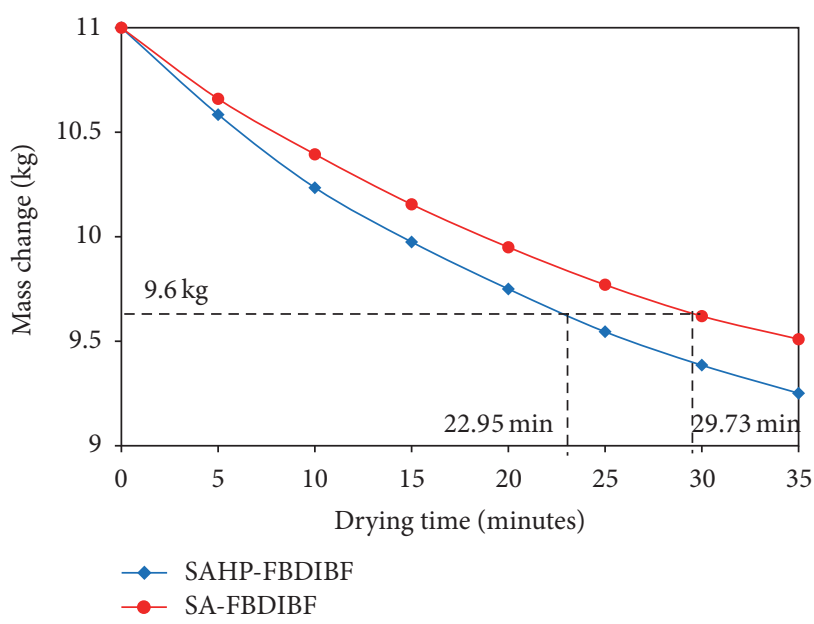

FIGURE 15: The variation of mass change with drying time.

decreased in the drying time. Also, as seen from Figures 13 and 14 the temperature at outlet (leaving) of the drying chamber is high and the relative humidity outlet (leaving) of the drying chamber is low, and it is potential for recirculating to dry the paddy.

The variations of mass change and moisture content of paddy with drying time for SAHP-FBDIBF and SA-FBDIBF are shown in Figures 15 and 16. Figure 15 shows the variation of mass change of paddy with drying time for SAHP-FBDIBF and SA-FBDIBF. The SA-FBDIBF reduced the mass of paddy from $11 \mathrm{~kg}$ to $9.51 \mathrm{~kg}$ under an air mass flow rate of $0.1037 \mathrm{~kg} / \mathrm{s}$, with average temperature and relative humidity which were $80.3^{\circ} \mathrm{C}$ and $12.28 \%$ within 35 minutes whereas the SAHPFBDIBF reduced the mass of paddy from $11 \mathrm{~kg}$ to $9.25 \mathrm{~kg}$ with average temperature and relative humidity which were $80.9^{\circ} \mathrm{C}$ and $8.14 \%$ in the same period. Figure 16 shows the variation of moisture content of paddy with drying time for SAHPFBDIBF and SA-FBDIBF. The moisture content of paddy in the SA-FBDIBF was reduced from $32.85 \%$ dry basis to $14.8557 \%$ dry basis within 35 minutes whereas the moisture 


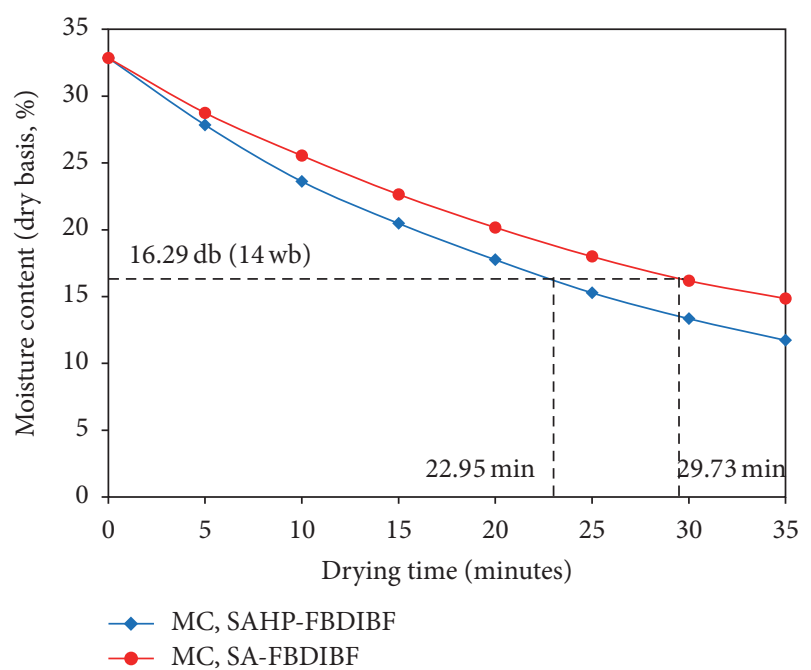

FIGURE 16: The variation of moisture content with drying time.

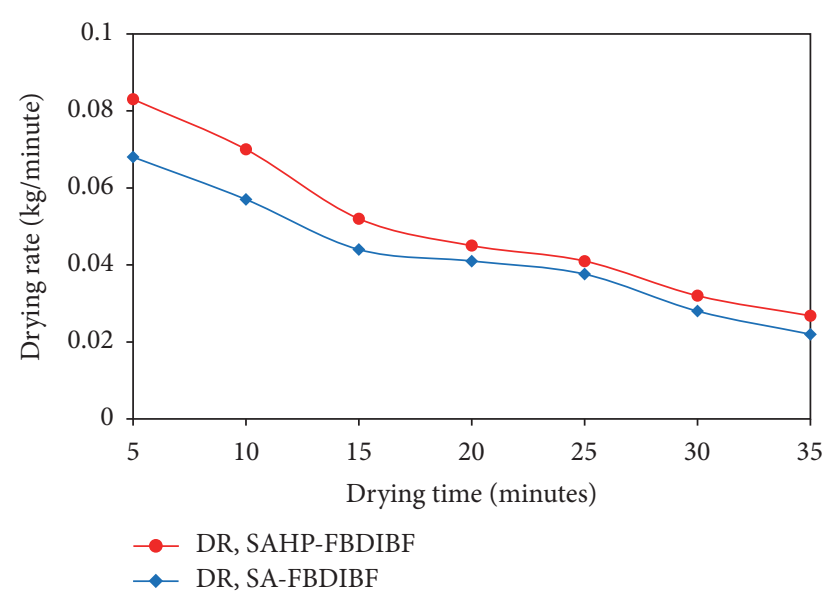

FIGURE 17: The variation of drying rate with drying time.

content of paddy in the SAHP-FBDIBF was reduced from $32.85 \%$ dry basis to $11.727 \%$ dry basis in the same period. As seen from Figures 15 and 16 in order to secure longterm storage and milling, the moisture content of paddy only needs to be reduced to $16.292 \%$ dry basis (14\% wet basis; $9.6 \mathrm{~kg}$ ). At the level of this moisture content the SAFBDIBF and SAHP-FBDIBF required 29.73 minutes and 22.95 minutes, respectively. The SAHP-FBDIBF had a shorter drying time compared to the SA-FBDIBF. In other words, the SAHP-FBDIBF reduced the drying time $22.81 \%$ compared to the SA-FBDIBF. This, due to its moisture content transfer rate, is higher than the SA-FBDIBF, and this caused by the difference in the partial vapour pressure between paddy and the drying air obtained in the SAHP-FBDIBF is higher than in the SA-FBDIBF. This difference value is very dependent on the drying air relative humidity, when drying air relative humidity is low; the difference in the partial vapour pressure between paddy and the drying air is also high and vice versa.

The variations of drying rate with drying time for SAHPFBDIBF and SA-FBDIBF are shown in Figure 17. The drying

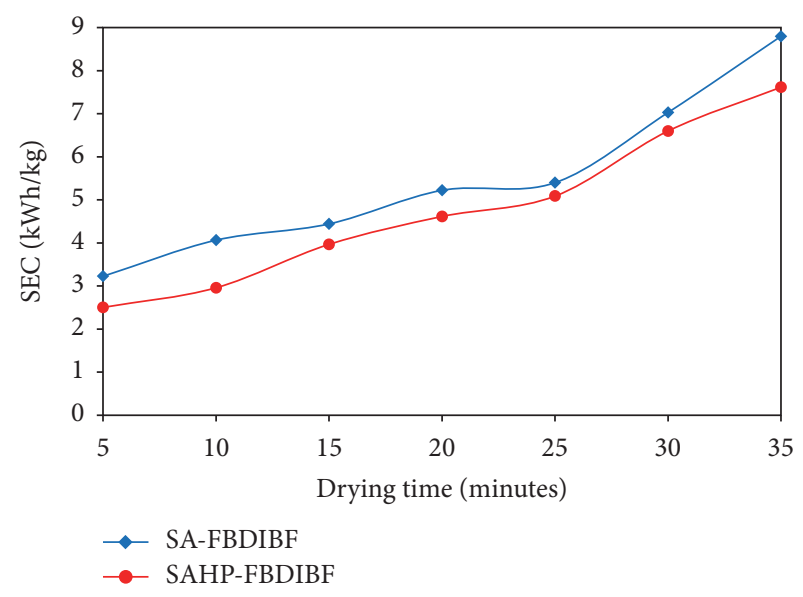

FIGURE 18: The variation of SEC with drying time.

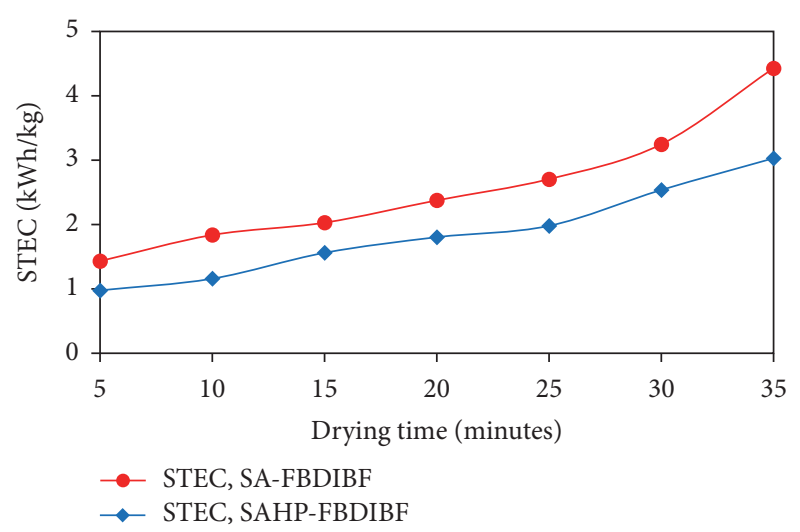

FIGURE 19: The variation of STEC with drying time.

rate of paddy was calculated in the range of $0.022 \mathrm{~kg} /$ minute$0.068 \mathrm{~kg} /$ minute and $0.027 \mathrm{~kg} /$ minute $-0.083 \mathrm{~kg} /$ minute, with average values of $0.043 \mathrm{~kg} / \mathrm{minute}$ and $0.050 \mathrm{~kg} /$ minute for SA-FBDIBF and SAHP-FBDIBF, respectively. As seen from Figure 17 the drying rate decreased with increase in drying time. This, due to the evaporation rate of moisture, decreased in the drying time.

The variations of SEC with drying time for SAHPFBDIBF and SA-FBDIBF are shown in Figure 18. The SEC ranged from $3.226 \mathrm{kWh} / \mathrm{kg}$ to $8.798 \mathrm{kWh} / \mathrm{kg}$ for SA-FBDIBF and from $2.502 \mathrm{kWh} / \mathrm{kg}$ to $7.615 \mathrm{kWh} / \mathrm{kg}$ for SAHP-FBDIBF, with average values of $5.454 \mathrm{kWh} / \mathrm{kg}$ and $4.763 \mathrm{kWh} / \mathrm{kg}$, respectively. As seen from Figure 18 the SEC increased with increase in drying time.

The variations of STEC and SEEC with drying time for SAHP-FBDIBF and SA-FBDIBF are shown in Figures 19 and 20. Figure 19 shows the variation of STEC with drying time for SAHP-FBDIBF and SA-FBDIBF. The STEC was calculated in the range of $1.434 \mathrm{kWh} / \mathrm{kg}-4.427 \mathrm{kWh} / \mathrm{kg}$ and $0.978 \mathrm{kWh} / \mathrm{kg}-3.029 \mathrm{kWh} / \mathrm{kg}$, with average values of $2.579 \mathrm{kWh} / \mathrm{kg}$ and $1.864 \mathrm{kWh} / \mathrm{kg}$ for SA-FBDIBF and SAHPFBDIBF, respectively. Figure 20 shows the variation of SEEC with drying time for SAHP-FBDIBF and SA-FBDIBF. 


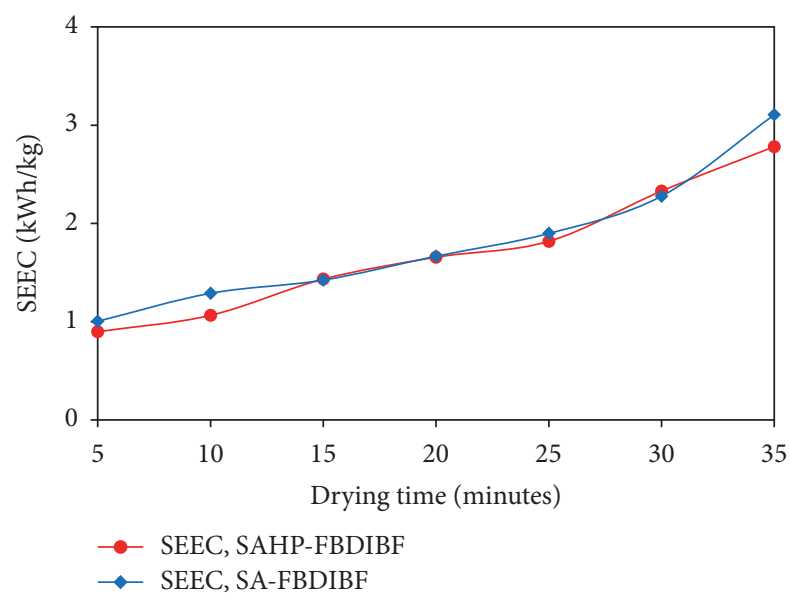

FIgURE 20: The variation of SEEC with drying time.

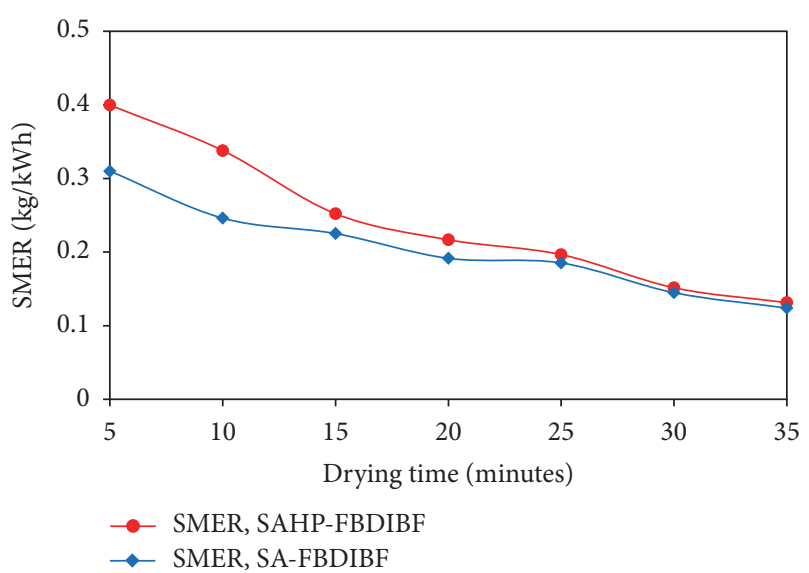

FIGURE 21: The variation of SMER with drying time.

The SEEC was calculated in the range of $1.005 \mathrm{kWh} / \mathrm{kg}-$ $3.106 \mathrm{kWh} / \mathrm{kg}$ and $0.898 \mathrm{kWh} / \mathrm{kg}-2.781 \mathrm{kWh} / \mathrm{kg}$, with average values of $1.809 \mathrm{kWh} / \mathrm{kg}$ and $1.712 \mathrm{kWh} / \mathrm{kg}$ for SA-FBDIBF and SAHP-FBDIBF, respectively. As seen from Figures 19 and 20 the STEC and SEEC increased with increase in drying time.

The variations of SMER and dryer thermal efficiency with drying time for SAHP-FBDIBF and SA-FBDIBF are shown in Figures 21 and 22. Figure 21 shows the variations of SMER with drying time for SAHP-FBDIBF and SA-FBDIBF. The SMER ranged from $0.124 \mathrm{~kg} / \mathrm{kWh}$ to $0.310 \mathrm{~kg} / \mathrm{kWh}$ and $0.131 \mathrm{~kg} / \mathrm{kWh}$ to $0.399 \mathrm{~kg} / \mathrm{kWh}$, with average values of $0.204 \mathrm{~kg} / \mathrm{kWh}$ and $0.241 \mathrm{~kg} / \mathrm{kWh}$ for SA-FBDIBF and SAHPFBDIBF, respectively. Figure 22 shows the dryer thermal efficiency with drying time for SAHP-FBDIBF and SAFBDIBF. The dryer thermal efficiencies ranged from $7.29 \%$ to $19.88 \%$ and $8.42 \%$ to $25.63 \%$, with average values of $12.28 \%$ and $15.44 \%$ for SA-FBDIBF and SAHP-FBDIBF, respectively.

The variations of pickup efficiency with drying time for SAHP-FBDIBF and SA-FBDIBF are shown in Figure 23. The pickup efficiencies were calculated in the range of $20.55 \%-$ $62.08 \%$ and $23.69 \%-73.40 \%$, with average values of $33.55 \%$ and $43.84 \%$ for SA-FBDIBF and SAHP-FBDIBF, respectively.

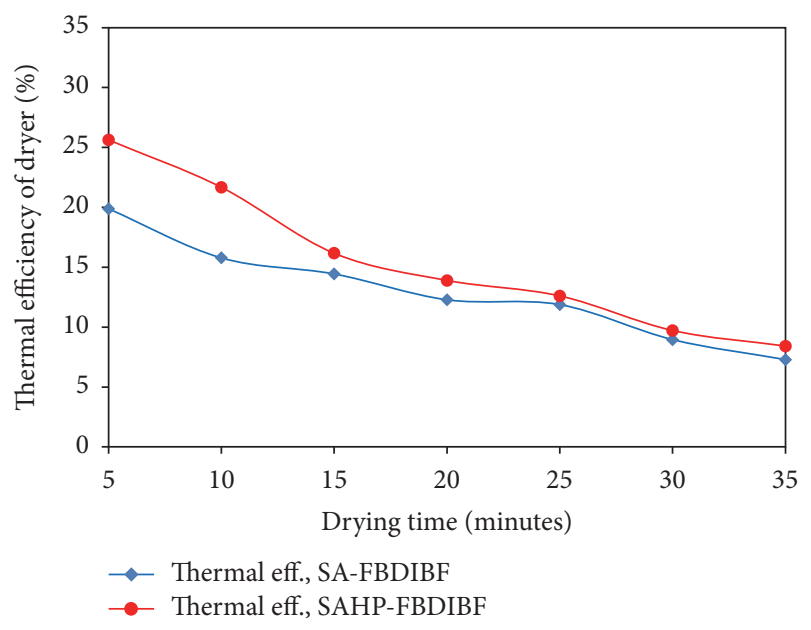

FIGURE 22: The variation of thermal efficiency with drying time.

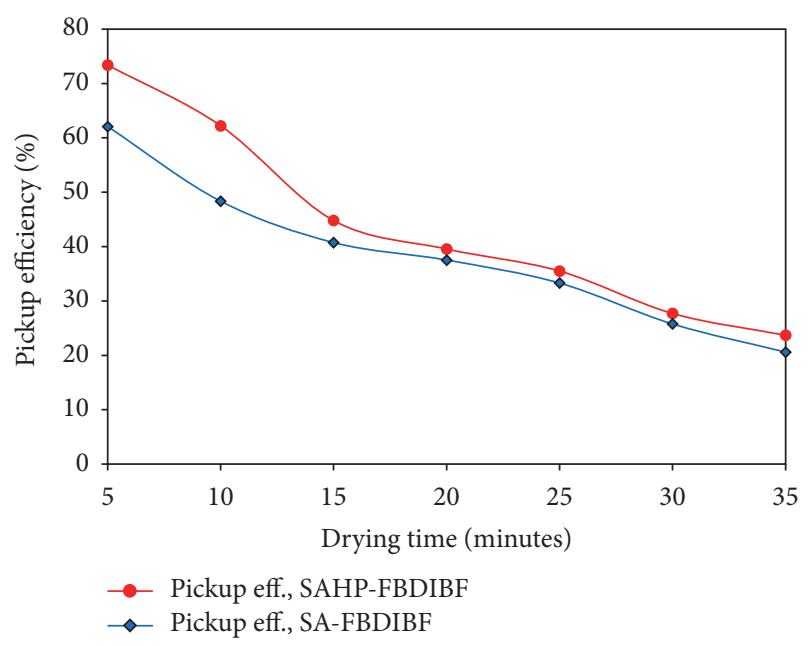

FIgURE 23: The variation of pickup efficiency with drying time.

As seen from Figure 23 the pickup efficiency of the SAHPFBDIBF is higher than the SA-FBDIBF. This, due to the evaporation rate of moisture in the SAHP-FBDIBF, is higher than the SA-FBDIBF.

The variations of the energy fraction with drying time for SAHP-FBDIBF and SA-FBDIBF are shown in Figure 24. The solar fraction by the solar energy ranged from $7.2 \%$ to $16.2 \%$ for SA-FBDIBF and from $9.4 \%$ to $11.7 \%$ for SAHPFBDIBF, with average values of $10.9 \%$ and $10.6 \%$, respectively. The biomass fraction by the biomass energy ranged from $31.6 \%$ to $43.6 \%$ for SA-FBDIBF and from $27.8 \%$ to $31.7 \%$ for SAHP-FBDIBF, with average values of $36.6 \%$ and $30.4 \%$, respectively.

Table 3 shows a summary of the experimental results for drying of paddy by using the SA-FBDIBF and SAHP-FBDIBF. The results revealed the SAHP-FBDIBF is better than the SA-FBDIBF. This, due to the drying rate, SMER, thermal efficiency of dryer, and pickup efficiency, is higher than the SA-FBDIBF. 


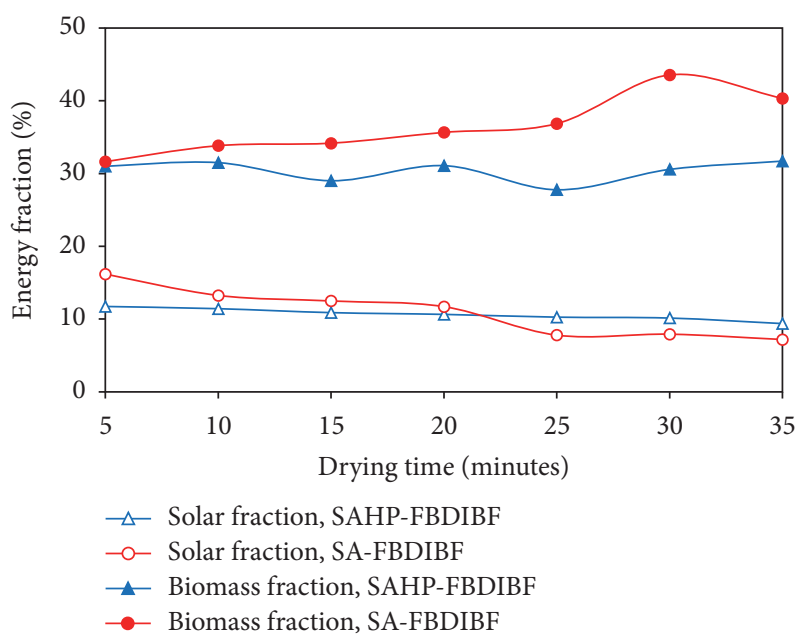

FIgURE 24: The variation of the energy fraction with drying time.

TABLE 3: Performance evaluation of the SA-FBDIBF and SAHPFBDIBF for drying of paddy.

\begin{tabular}{|c|c|c|c|}
\hline Parameters & Unit & SA-FBDIBF & SAHP-FBDIBF \\
\hline Initial mass of paddy & $\mathrm{kg}$ & 11 & 11 \\
\hline Final mass of paddy & $\mathrm{kg}$ & 9.62 & 9.62 \\
\hline $\begin{array}{l}\text { Initial moisture } \\
\text { content of paddy (dry } \\
\text { basis) }\end{array}$ & $\%$ & 32.85 & 32.85 \\
\hline $\begin{array}{l}\text { Final moisture } \\
\text { content of paddy (dry } \\
\text { basis) }\end{array}$ & $\%$ & 16.29 & 16.29 \\
\hline Air mass flow rate & $\mathrm{kg} / \mathrm{s}$ & 0.1037 & 0.1037 \\
\hline $\begin{array}{l}\text { Average efficiency of } \\
\text { solar collector }\end{array}$ & $\%$ & 58.20 & 50.51 \\
\hline $\begin{array}{l}\text { Average COP of heat } \\
\text { pump }\end{array}$ & - & - & 3.74 \\
\hline $\begin{array}{l}\text { Average efficiency of } \\
\text { biomass furnace }\end{array}$ & $\%$ & 75.57 & 77.49 \\
\hline $\begin{array}{l}\text { Average drying } \\
\text { chamber temperature }\end{array}$ & ${ }^{\circ} \mathrm{C}$ & 80.3 & 80.9 \\
\hline $\begin{array}{l}\text { Average drying } \\
\text { chamber relative } \\
\text { humidity }\end{array}$ & $\%$ & 12.28 & 8.14 \\
\hline Drying time & Minutes & 29.73 & 22.95 \\
\hline Average drying rate & $\mathrm{kg} /$ minutes & 0.043 & 0.050 \\
\hline Average SEC & $\mathrm{kWh} / \mathrm{kg}$ & 5.454 & 4.763 \\
\hline Average STEC & $\mathrm{kWh} / \mathrm{kg}$ & 2.579 & 1.864 \\
\hline Average SEEC & $\mathrm{kWh} / \mathrm{kg}$ & 1.809 & 1.712 \\
\hline Average SMER & $\mathrm{kg} / \mathrm{kWh}$ & 0.204 & 0.241 \\
\hline $\begin{array}{l}\text { Average thermal } \\
\text { efficiency of dryer }\end{array}$ & $\%$ & 12.28 & 15.54 \\
\hline $\begin{array}{l}\text { Average pickup } \\
\text { efficiency }\end{array}$ & $\%$ & 33.55 & 43.84 \\
\hline $\begin{array}{l}\text { Average solar energy } \\
\text { fraction }\end{array}$ & $\%$ & 10.9 & 10.6 \\
\hline $\begin{array}{l}\text { Average biomass } \\
\text { energy fraction }\end{array}$ & $\%$ & 36.6 & 30.4 \\
\hline
\end{tabular}

The variations of dimensionless moisture content data of dried paddy in a SAHP-FBDIBF and a SA-FBDIBF with

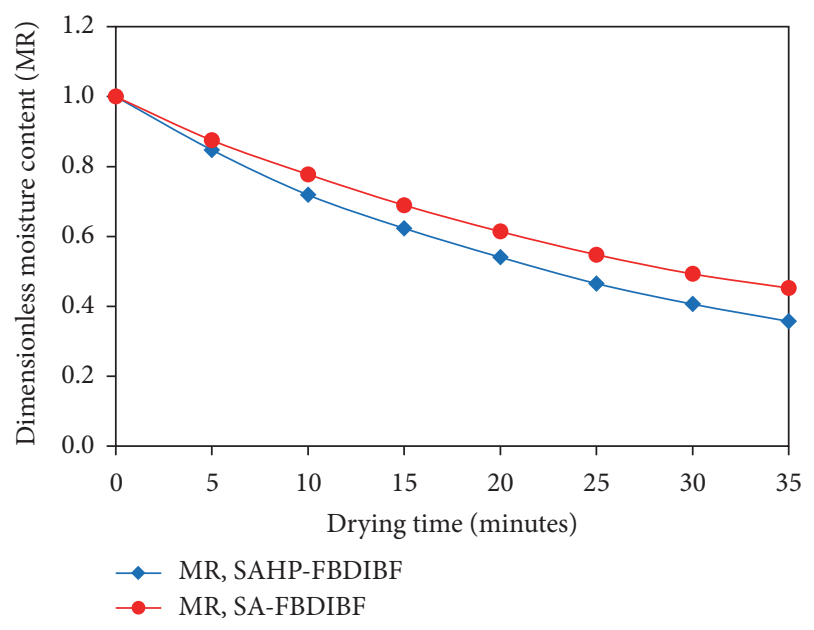

FIGURE 25: The variation of dimensionless moisture content with drying time.

drying time are shown in Figure 25. The dimensionless moisture content of paddy reduced exponentially as the drying time increased. Continuous decreasing in dimensionless moisture content indicates that diffusion has governed the internal mass transfer. As seen from Figure 25 the reduction of moisture content of paddy dried using SAHP-FBDIBF is faster than the SA-FBDIBF; this due to the air drying relative humidity is lower than the SA-FBDIBF. At low relative humidity, the difference in partial vapour pressure between paddy and the air drying is high; thereby the acceleration of moisture migration is also high.

The dimensionless moisture content data of dried paddy in a SAHP-FBDIBF and a SA-FBDIBF were fitted in three drying models such as the Newton model, Henderson-Pabis model, and the Page model. The regression constant, the values of the coefficient of determination $\left(R^{2}\right)$, the mean bias error (MBE), and the root mean-square error (RMSE) for these drying models are given in Table 4 . It can be observed in Table 4 that the Page model fitted best with the experimental data compared to the Newton and Henderson-Pabis drying models; this due to the values of $R^{2}$ is higher, and MBE and RMSE are lower than the Newton and Henderson-Pabis drying models. Page model for drying of paddy using a SAHP-FBDIBF gave $R^{2}=0.9998, \mathrm{MBE}=0.0000093$, and RMSE $=0.00305$. Meanwhile, Page model for drying of paddy using a SA-FBDIBF gave $R^{2}=0.9996, \mathrm{MBE}=0.0000145$, and $\mathrm{RMSE}=0.00381$.

The plots of the experimental dimensionless moisture content (MR) with predicted dimensionless moisture content (MR) from the Page models for SA-FBDIBF and SAHPFBDIBF are shown in Figures 26 and 27. The data indicate the suitability of the developed model to describe the drying behaviour of paddy.

The variations of drying rate with dimensionless moisture content of dried paddy in a SAHP-FBDIBF and a SA-FBDIBF are shown in Figure 28. Drying of paddy occurred in falling rate period; constant drying rate period was not found. During the falling rate period, the drying rate decreased 
TABLE 4: Statistical results mathematical modelling of drying curves.

\begin{tabular}{lcccc}
\hline Model & Method of drying & $\begin{array}{c}\text { Model coefficients and } \\
\text { constants }\end{array}$ & $R^{2}$ & MBE \\
\hline \multirow{2}{*}{ Newton } & SA-FBDIBF & $k=0.1180$ & 0.9959 & 0.00012 \\
& SAHP-FBDIBF & $k=0.1510$ & 0.9974 & 0.00013 \\
\multirow{2}{*}{ Henderson and Pabis } & SA-FBDIBF & $k=0.1142 ; a=1.0189$ & 0.9975 & 0.00086 \\
& SAHP-FBDIBF & $k=0.1468 ; a=1.0213$ & 0.9985 & 0.00091 \\
Page & SA-FBDIBF & $k=0.9268 ; n=0.1337$ & 0.9996 & 0.0000145 \\
& SAHP-FBDIBF & $k=0.9368 ; n=0.1684$ & 0.9998 & 0.00000093 \\
\hline
\end{tabular}

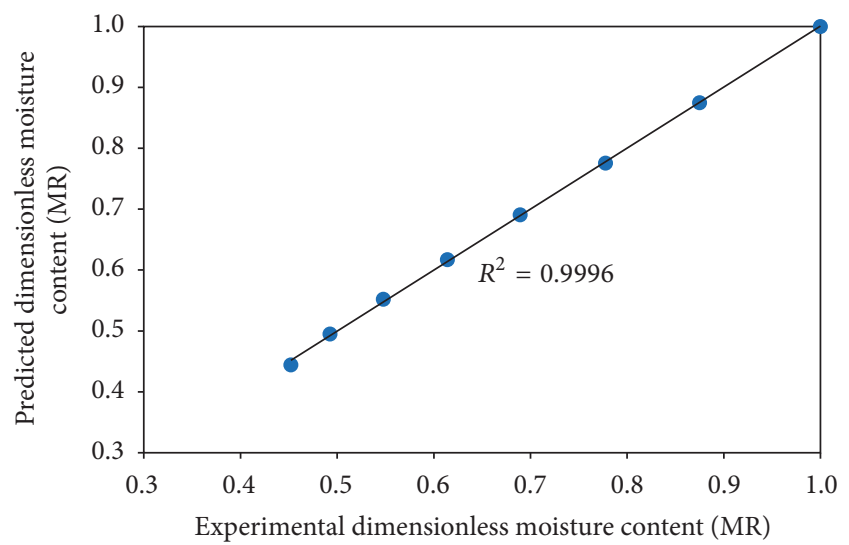

FIGURE 26: Comparison of experimental dimensionless moisture content (MR) with predicted dimensionless moisture content (MR) from the Page model for the SA-FBDIBF for drying of paddy.

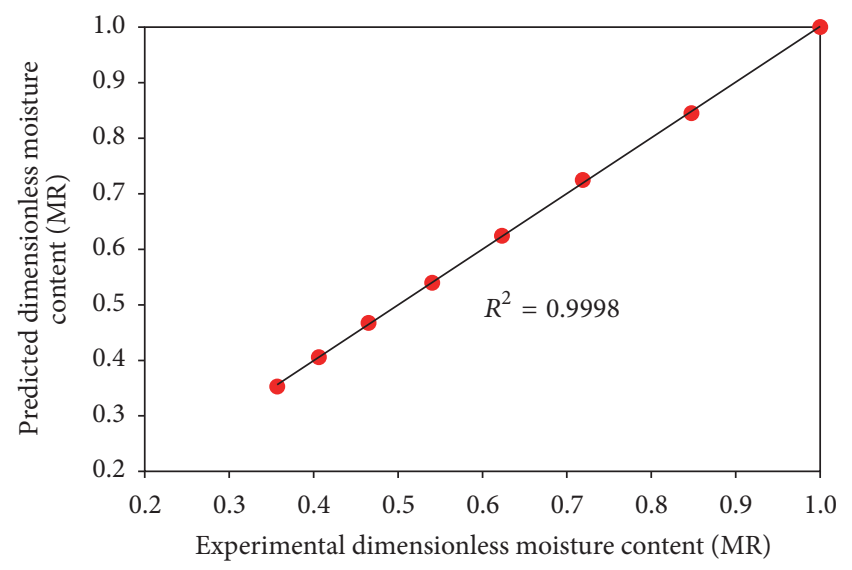

Figure 27: Comparison of experimental dimensionless moisture content (MR) with predicted dimensionless moisture content (MR) from the Page model for the SAHP-FBDIBF for drying of paddy.

continuously with decreasing dimensionless moisture content and increasing drying time. These are similar results as the observation of earlier researcher [44]. From the curve of drying rate with dimensionless moisture content of paddy, the regression equations are as follows.

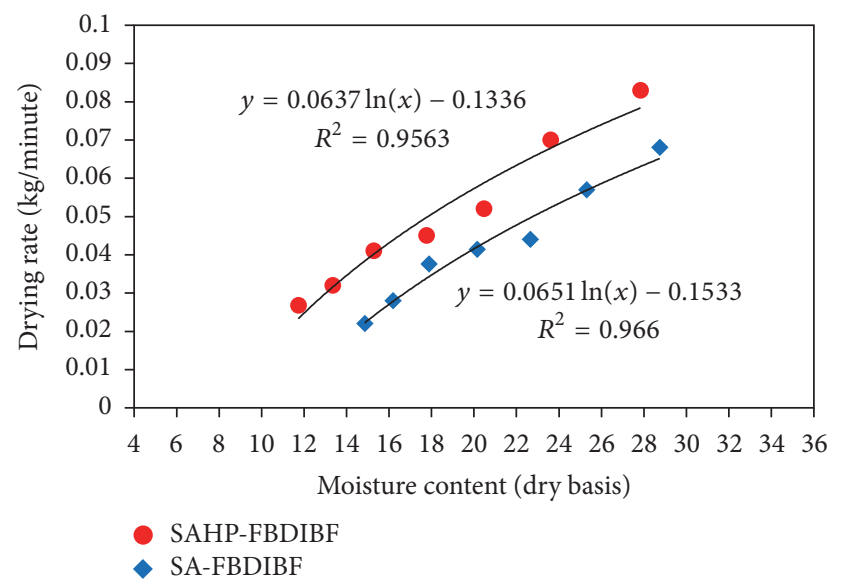

FIGURE 28: The variation of drying rate with moisture content dry basis.

\section{For SA-FBDIBF,}

$\mathrm{DR}=0.1533+0.0651 \ln (\mathrm{MR}) ; \quad R^{2}=0.966$

For SAHP-FBDIBF,

$\mathrm{DR}=0.1336+0.0637 \ln (\mathrm{MR}) ; \quad R^{2}=0.9563$.

\section{Conclusion}

The performances of a solar assisted fluidized bed dryer integrated biomass furnace (SA-FBDIBF) and a solar assisted heat pump fluidized bed dryer integrated biomass furnace (SAHP-FBDIBF) for drying of paddy have been evaluated, and also drying kinetics of paddy were evaluated. The SAFBDIBF and the SAHP-FBDIBF were used to dry paddy from $11 \mathrm{~kg}$ with moisture content of $32.85 \% \mathrm{db}$ to moisture content of $16.29 \% \mathrm{db}(14 \% \mathrm{wb})$ under an air mass flow rate of $0.1037 \mathrm{~kg} / \mathrm{s}$ within 29.73 minutes and 22.95 minutes, with average temperatures and relative humidities of $80.3^{\circ} \mathrm{C}$ and $80.9^{\circ} \mathrm{C}$ and $12.28 \%$ and $8.14 \%$, respectively. The collector efficiencies and biomass furnace efficiencies were calculated with average values of $58.20 \%$ and $50.51 \%$, and $75.57 \%$ and $77.49 \%$ for SA-FBDIBF and SAHP-FBDIBF, respectively. The average $\mathrm{COP}$ of the heat pump was calculated on an average of 
3.74. The average drying rate and specific moisture extraction rate were estimated as $0.043 \mathrm{~kg} /$ minute and $0.050 \mathrm{~kg} /$ minute and $0.204 \mathrm{~kg} / \mathrm{kWh}$ and $0.241 \mathrm{~kg} / \mathrm{kWh}$ for SA-FBDIBF and SAHP-FBDIBF, respectively. The specific energy consumption, specific thermal energy consumption, and specific electrical energy consumption were calculated with average values of $5.454 \mathrm{kWh} / \mathrm{kg}$ and $4.763 \mathrm{kWh} / \mathrm{kg}, 2.579 \mathrm{kWh} / \mathrm{kg}$ and $1.864 \mathrm{kWh} / \mathrm{kg}$, and $1.809 \mathrm{kWh} / \mathrm{kg}$ and $1.712 \mathrm{kWh} / \mathrm{kg}$ for SA-FBDIBF and SAHP-FBDIBF, respectively. The dryer thermal efficiencies and pickup efficiencies were average values of $12.28 \%$ and $15.44 \%$, and $33.55 \%$ and $43.84 \%$ for SA-FBDIBF and SAHP-FBDIBF, respectively, whereas the average solar and biomass fractions were $10.9 \%$ and $10.6 \%$, and $36.6 \%$ and $30.4 \%$ for SA-FBDIBF and SAHP-FBDIBF, respectively. The drying of paddy occurred in the falling rate period. The experimental dimensionless moisture ratio data were fitted to three mathematical models. Page's model was found best to describe the drying behaviour of paddy. Result shows that the SAHP-FBDIBF is better than the SA-FBDIBF; this due to the performance is higher than the SA-FBDIBF.

\section{Nomenclature}

$A_{\mathrm{SC}}: \quad$ Area of solar collector $\left(\mathrm{m}^{2}\right)$

$\cos \varphi$ : Power factor

$a$ : Drying constant

MBE: Mean bias error

$C_{P_{\text {air }}}: \quad$ Specific heat of air $\left(\mathrm{Jkg}^{-1} \mathrm{C}^{-1}\right)$

I: $\quad$ Line current (ampere)

$I_{T}: \quad$ Solar radiation $\left(\mathrm{Wm}^{-2}\right)$

$\dot{m}_{\text {air }}$ : Air mass flow rate $(\mathrm{kg} / \mathrm{s})$

$\dot{m}_{\text {bmf }}:$ Biomass fuel consumption rate $(\mathrm{kg} / \mathrm{h})$

$\dot{m}_{\mathrm{da}}: \quad$ Mass flow of dry air $\left(\mathrm{kg}_{\text {dry air }} / \mathrm{s}\right)$

$\dot{m}_{\text {water }}$ : Mass of water evaporation rate $(\mathrm{kg} / \mathrm{h})$

$m_{\text {wetp }}$ : Mass of wet paddy $(\mathrm{kg})$

$V: \quad$ Line voltage (volt)

$\mathrm{CV}_{\mathrm{bmf}}$ : Caloric value of biomass fuel $(\mathrm{kcal} / \mathrm{kg})$

$H_{f g}$ : Latent heat of vapourization of water $(\mathrm{J} / \mathrm{kg})$

$m_{d}$ : $\quad$ Mass of bone dry of paddy $(\mathrm{kg})$

$M_{e}: \quad$ Equilibrium moisture content in dry basis (\%)

$M_{\mathrm{wb}, f}$ : Final moisture content in wet basis (\%)

$M_{\mathrm{wb}, i}$ : Initial moisture content in wet basis (\%)

$M_{o}: \quad$ Initial moisture content in dry basis (\%)

$M_{t}: \quad$ Moisture content at any time in dry basis (\%)

$N$ : Number of observations

$n$ : Drying contant

$R^{2}$ : Coefficient of determination

RMSE: Root mean-square error

T: $\quad$ Temperature $\left({ }^{\circ} \mathrm{C}\right)$

$W_{\mathrm{BC}}$ : Electrical energy consumed by blower of cyclone $(\mathrm{kW})$

$W_{\mathrm{BFD}}$ : Electrical energy consumed by blower of fluidized bed (kW)

$W_{\text {Comp }}$ : Electrical energy consumed by compressor $(\mathrm{kW})$
$Y_{\mathrm{as}}$ : Adiabatic saturation humidity of air $\left(\mathrm{kg}_{\text {water }} / \mathrm{kg}_{\text {dry air }}\right)$

$Y_{i}$ : Absolute humidity of air $\left(\mathrm{kg}_{\text {water }} / \mathrm{kg}_{\text {dry air }}\right)$.

Subscripts

BF: Biomass furnace

Comp: Compressor

Cond: Condenser

hp: Heat pump

SC: Solar collector.

\section{Competing Interests}

The author declared that this article currently has no conflict of interests.

\section{Acknowledgments}

The author would like to thank Higher Education Directorate of Education and Cultural Ministry of Indonesia (DIKTI) for research funding through the Hibah Bersaing Research grant scheme.

\section{References}

[1] BPS (Badan Pusat Statistik Indonesia), Statistik Indonesia, BPS, Jakarta, Indonesia, 2015.

[2] H. K. Purwadaria, "Problems and priorities of grain drying in Indonesia," in Proceedings of the International Conference Grain Drying in Asia, vol. 71 of ACIAR Proceedings, pp. 201209, 74 FAO Regional Office for Asia and the Pacific, Bangkok, Thailand, 1995.

[3] C. Bonazzi, M. A. du Peuty, and A. Themelin, "Influence of drying conditions on the processing quality of rough rice," Drying Technology, vol. 15, no. 3-4, pp. 1141-1157, 1997.

[4] M. Izadifar and D. Mowla, "Simulation of a cross-flow continuous fluidized bed dryer for paddy rice," Journal of Food Engineering, vol. 58, no. 4, pp. 325-329, 2003.

[5] R. Sivakumar, R. Saravanan, A. Elaya Perumal, and S. Iniyan, "Fluidized bed drying of some agro products-a review," Renewable and Sustainable Energy Reviews, vol. 61, pp. 280-301, 2016.

[6] A. S. Kassem, A. Z. Shokr, A. R. El-Mahdy, A. M. Aboukarima, and E. Y. Hamed, "Comparison of drying characteristics of Thompson seedless grapes using combined microwave oven and hot air drying," Journal of the Saudi Society of Agricultural Sciences, vol. 10, no. 1, pp. 33-40, 2011.

[7] S. Soponronnarit, M. Yapha, and S. Prachayawarakorn, "Crossflow fluidized bed paddy dryer: prototype and commercialization," Drying Technology, vol. 13, no. 8-9, pp. 2207-2216, 1995.

[8] M. N. Ibrahim, M. S. H. Sarker, N. Ab Aziz, and P. M. Salleh, "Drying performances and milling quality of rice during industrial fluidized bed drying of paddy in Malaysia," Pertanika Journal of Science and Technology, vol. 23, no. 2, pp. 297-309, 2015.

[9] M. Yahya, "Design and performance evaluation of a solar assisted heat pump dryer integrated with biomass furnace 
for red chilli," International Journal of Photoenergy, vol. 2016, Article ID 8763947, 14 pages, 2016.

[10] J. O. Akowuah, A. Addo, and A. B. Plauge, "Influence of drying temperature and storage duration on fissuring and milling quality of Jasmin 85 rice variety," Journal of Science and Technology, vol. 32, no. 2, pp. 26-33, 2012.

[11] P. Jaiboon, S. Prachayawarakorn, S. Devahastin, and S. Soponronnarit, "Effects of fluidized bed drying temperature and tempering time on quality of waxy rice," Journal of Food Engineering, vol. 95, no. 3, pp. 517-524, 2009.

[12] D. A. Schluterman and T. J. Siebenmorgen, "Relating rough rice moisture content reduction and tempering duration to head rice yield reduction," Transactions of the ASABE, vol. 50, no. 1, pp. 137-142, 2007.

[13] A. Karbassi and Mehdizadeh, "Drying rough rice in a fluidized bed dryer," Journal of Agricultural Science and Technology, vol. 14, pp. 233-241, 2008.

[14] M. M. S. Dezfouli, S. Mat, M. H. Ruslan, and K. Sopian, "Evaluation of drying chili by two methods: solar assisted heat pump dryer and open sun drying," in Proceedings of the 1st International Conference on Environmental Informatics (ENINF '13), pp. 112-116, Kuala Lumpur, Malaysia, 2013.

[15] S. Şevik, M. Aktaş, H. Doğan, and S. Koçak, "Mushroom drying with solar assisted heat pump system," Energy Conversion and Management, vol. 72, pp. 171-178, 2013.

[16] M. Mohanraj, "Performance of a solar-ambient hybrid source heat pump drier for copra drying under hot-humid weather conditions," Energy for Sustainable Development, vol. 23, pp. 165-169, 2014.

[17] N. A. Handayani and D. Ariyanti, "Potency of solar energy application in Indonesia," International Journal of Renewable Energy Development, vol. 1, no. 2, pp. 33-38, 2012.

[18] B. Prastowo, "Biomass resource in Indonesia: Indonesia's solid biomass energy potential," in Proceedings of the IndonesiaGerman Workshop and Seminar, pp. 1-15, Institute Technology of Bandung, September 2011.

[19] S. Şevik, "Experimental investigation of a new design solar-heat pump dryer under the different climatic conditions and drying behavior of selected products," Solar Energy, vol. 105, pp. 190205, 2014.

[20] E. K. Akpinar and Y. Bicer, "Mathematical modelling of thin layer drying process of long green pepper in solar dryer and under open sun," Energy Conversion and Management, vol. 49, no. 6, pp. 1367-1375, 2008.

[21] I. Ceylan and M. Aktaş, "Modeling of a hazelnut dryer assisted heat pump by using artificial neural networks," Applied Energy, vol. 85, no. 9, pp. 841-854, 2008.

[22] S. Kooli, A. Fadhel, A. Farhat, and A. Belghith, "Drying of red pepper in open sun and greenhouse conditions. Mathematical modeling and experimental validation," Journal of Food Engineering, vol. 79, no. 3, pp. 1094-1103, 2007.

[23] A. Fudholi, M. Y. Othman, M. H. Ruslan, and K. Sopian, "Drying of malaysian Capsicum annuum L. (Red Chili) dried by open and solar drying," International Journal of Photoenergy, vol. 2013, Article ID 167895, 9 pages, 2013.

[24] I. Ceylan, M. Aktaş, and H. Doğan, "Energy and exergy analysis of timber dryer assisted heat pump," Applied Thermal Engineering, vol. 27, no. 1, pp. 216-222, 2007.

[25] M. Fatouh, M. N. Metwally, A. B. Helali, and M. H. Shedid, "Herbs drying using a heat pump dryer," Energy Conversion and Management, vol. 47, no. 15-16, pp. 2629-2643, 2006.
[26] A. Fudholi, K. Sopian, M. Y. Othman, and M. H. Ruslan, "Energy and exergy analyses of solar drying system of red seaweed," Energy and Buildings, vol. 68, pp. 121-129, 2014.

[27] M. S. H. Sarker, M. N. Ibrahim, N. A. Aziz, and M. S. Punan, "Application of simulation in determining suitable operating parameters for industrial scale fluidized bed dryer during drying of high impurity moist paddy," Journal of Stored Products Research, vol. 61, pp. 76-84, 2015.

[28] M. N. Ibrahim, M. S. H. Sarker, N. A. B. Aziz, and M. Salleh, "Drying performance and overall energy requisite of industrial inclined bed paddy drying in Malaysia," Journal of Engineering Science and Technology, vol. 9, no. 3, pp. 398-409, 2014.

[29] J. Banout, P. Ehl, J. Havlik, B. Lojka, Z. Polesny, and V. Verner, "Design and performance evaluation of a Double-pass solar drier for drying of red chilli (Capsicum annum L.)," Solar Energy, vol. 85, no. 3, pp. 506-515, 2011.

[30] M. Yahya, A. Fudholi, H. Hafizh, and K. Sopian, "Comparison of solar dryer and solar-assisted heat pump dryer for cassava," Solar Energy, vol. 136, pp. 606-613, 2016.

[31] M. N. A. Hawlader, S. K. Chou, and M. Z. Ullah, "The performance of a solar assisted heat pump water heating system," Applied Thermal Engineering, vol. 21, no. 10, pp. 1049-1065, 2001.

[32] T. Swasdisevi, S. Soponronnarit, A. Shujinda, S. Wetchacama, and V. Thepent, "Rice husk furnace for fluidized bed paddy dryer," in Proceedings of the 2nd ASEAN Renewable Energy Conference, pp. 603-612, Phuket, Thailand, 1997.

[33] A. Triyono, Skripsi: Karakteristik Briket Arang Dari Campuran Serbuk Gergajian Kayu Afrika dan Sengon Dengan Penambahan Tempurung Kelapa, Fakultas Kehutanan, Institut Pertanian Bogor, Bogor, Indonesia, 2006.

[34] A. M. Leon and S. Kumar, "Design and performance evaluation of a solar-assisted biomass drying system with thermal storage," Drying Technology, vol. 26, no. 7, pp. 936-947, 2008.

[35] K. Sacilik, A. K. Elicin, and G. Unal, "Drying kinetics of Üryani plum in a convective hot-air dryer," Journal of Food Engineering, vol. 76, no. 3, pp. 362-368, 2006.

[36] L. M. Diamante and P. A. Munro, "Mathematical modeling of hot air drying of sweet potato slices," International Journal of Food Science \& Technology, vol. 26, no. 1, pp. 99-109, 1991.

[37] E. K. Akpinar, "Drying of mint leaves in a solar dryer and under open sun: modelling, performance analyses," Energy Conversion and Management, vol. 51, no. 12, pp. 2407-2418, 2010.

[38] R. K. Goyal, A. R. P. Kingsly, M. R. Manikantan, and S. M. Ilyas, "Mathematical modelling of thin layer drying kinetics of plum in a tunnel dryer," Journal of Food Engineering, vol. 79, no. 1, pp. 176-180, 2007.

[39] M. Aktaş, I. Ceylan, and S. Yilmaz, "Determination of drying characteristics of apples in a heat pump and solar dryer," Desalination, vol. 238, no. 1-3, pp. 266-275, 2009.

[40] K. Sacilik, R. Keskin, and A. K. Elicin, "Mathematical modelling of solar tunnel drying of thin layer organic tomato," Journal of Food Engineering, vol. 73, no. 3, pp. 231-238, 2006.

[41] I. Ceylan, M. Aktaş, and H. Doğan, "Mathematical modeling of drying characteristics of tropical fruits," Applied Thermal Engineering, vol. 27, no. 11-12, pp. 1931-1936, 2007.

[42] S. Arora, S. Bharti, and V. K. Sehgal, "Convective drying kinetics of red chillies," Drying Technology, vol. 24, no. 2, pp. 189-193, 2006. 
[43] S. Kaleemullah and R. Kailappan, "Drying kinetics of red chillies in a rotary dryer," Biosystems Engineering, vol. 92, no. 1, pp. 15-23, 2005.

[44] P. Luangmalawat, S. Prachayawarakorn, A. Nathakaranakule, and S. Soponronnarit, "Effect of temperature on drying characteristics and quality of cooked rice," LWT-Food Science and Technology, vol. 41, no. 4, pp. 716-723, 2008. 

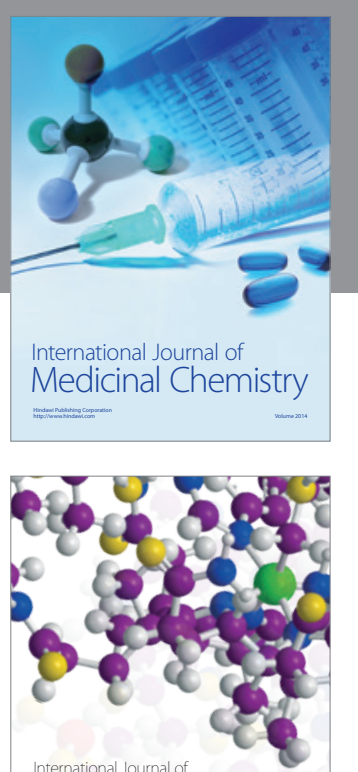

Carbohydrate Chemistry

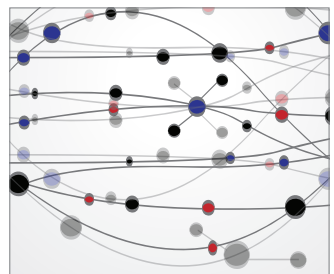

The Scientific World Journal
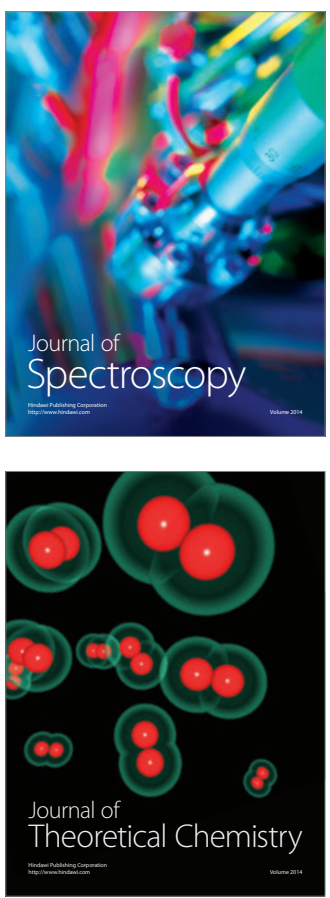
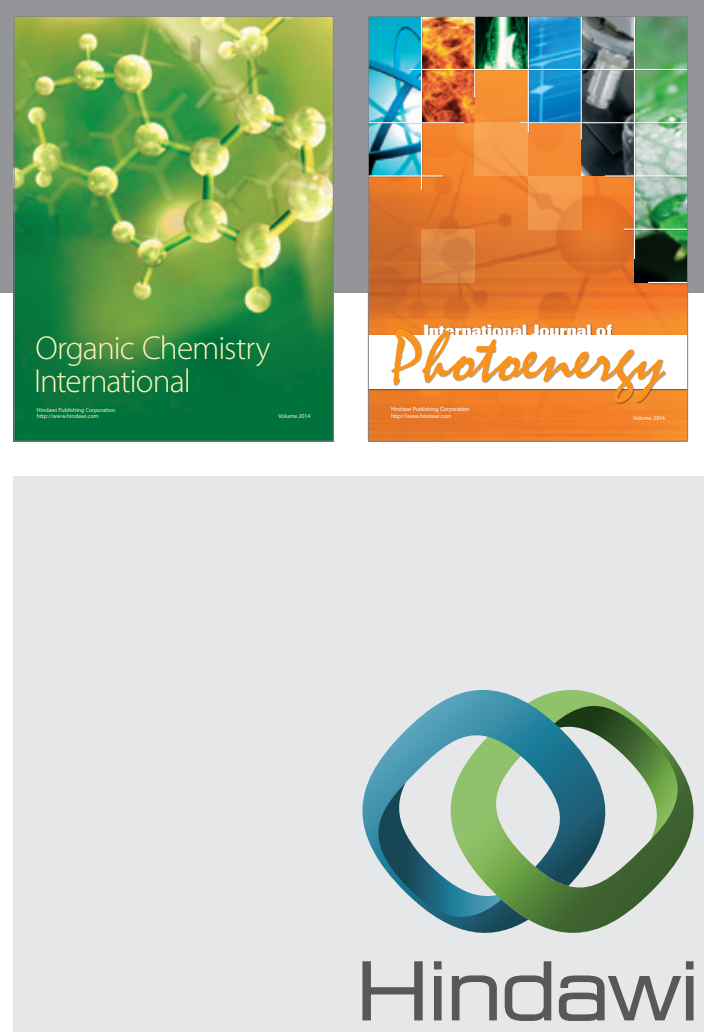

Submit your manuscripts at

http://www.hindawi.com

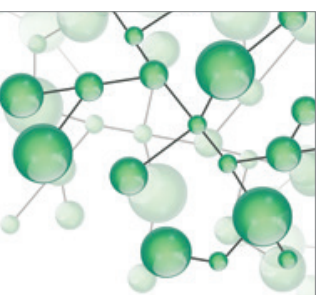

International Journal of

Inorganic Chemistry

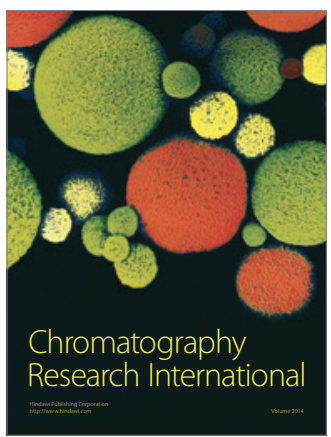

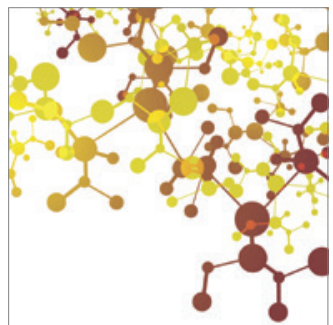

Applied Chemistry
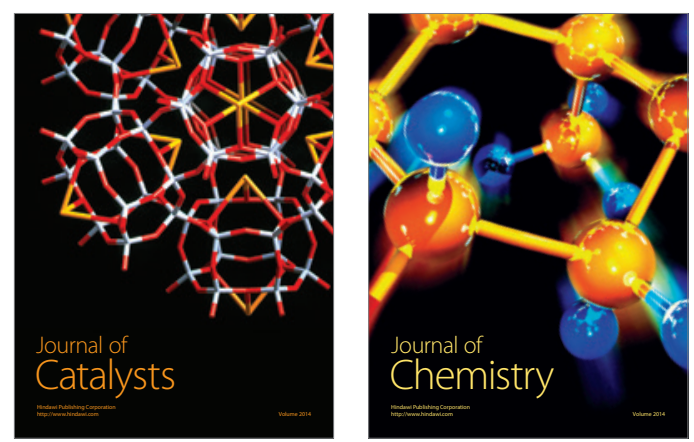
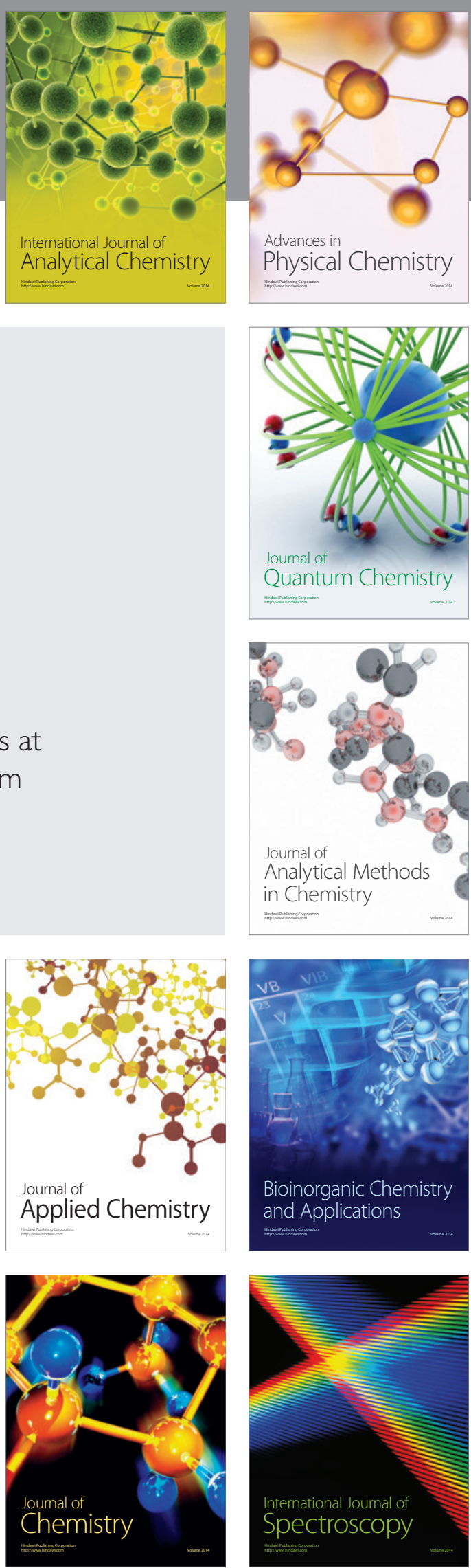